\title{
The Historic Architectural Legacy of the Chita Region in Eastern Siberia
}

\author{
William C. Brumfield* \\ Tulane University \\ New Orleans, Louisiana, USA
}

Received 12.04.2018, received in revised form 05.06.2018, accepted 12.06.2018

The article places the architectural heritage of the Chita territory (now known as Zabaikalskii krai) with a historical context extending from the mid-seventeenth century to the Soviet period. After a survey of events that led to Russian expansion and consolidation in the area, the text focuses on the architectural history of two urban centers: Nerchinsk and Chita. Each town was closely connected with the China trade. The article notes the work of Mikhail Butin, an entrepreneur and author who created an extensive base of operations in Nerchinsk. Special attention is given to George Kennan's notes on Nerchinsk in his two-volume work Siberia and the Exile System. Also included are Anton Chekhov's impressions. The latter part of the article traces the rise of Chita with the rapid development of the Trans-Siberian Railway at the turn of the twentieth century. Also noted are events surrounding the revolutions of 1905 and 1917, as well as the Russian Civil War.

Keywords: Architecture in Siberia, Chita, Nerchinsk, Albazin, Irkutsk, Lake Baikal, Ingoda River, Shilka River, Tsar Aleksei Mikhailovich, Peter Beketov, Afanasii Pashkov, Avvakum, Siberian Cossacks, Buriat people, Erofei Khabarov, Manchu Qing (Ch'ing) dynasty, Mikhail Butin, George Kennan, Siberia and the Exile System, Vasilii Kandinskii, Trans-Siberian Railway, Art nouveau design, style modern architecture, Aleksandr Vtorov, Chita synagogue, Ataman Grigorii Semenov.

DOI: 10.17516/1997-1370-0278.

Research area: culturology.

The Russian expansion towards the Far East during the middle of the seventeenth century was enabled by a network of rivers ranging from west to east beyond Lake Baikal. These include the westward flowing Khilok, which meets the Selenga near the eastern shore of Baikal, but has its origins far to the east, on the north flank of the upper Yablonovyi Range near the city of Chita. To the south of the Yablonovyi Range, the eastward flowing Ingoda empties into the Shilka, which in turn merges with the Amur at the northern Manchurian border. As Cossacks, fur traders, and fugitive peasants moved into this seemingly boundless space, the Muscovite government, faced with frequent wars along its western borders, struggled to establish its authority in eastern Siberia.

To that end the Yeniseisk voevoda, Afanasii Pashkov, had ample reason in 1652 to send the explorer and Cossack leader Peter Beketov (ca. 1600-1661?) back to the Transbaikal area, where he had been in 1628 as part of a campaign to

(c) Siberian Federal University. All rights reserved

* Corresponding author E-mail address: william.brumfield@gmail.com 
impose tribute on the Buriats. After establishing a fort at Lake Irgen (on the upper Khilok River) and crossing the Yablonovyi Range in late fall of 1653, Beketov made a winter camp (zimov'e) on the Ingoda River near its confluence with the Chita. A permanent settlement on the site did not appear until 1675 , and the town that would eventually be known as Chita did not acquire major significance until the second half of the nineteenth century.

Power in the area lay farther east, and this was the ultimate goal of Beketov's mission. Before returning to the Irgen ostrog, he sent a small detachment under Maksim Urazov to establish a fort known as Neliudskii, on the Shilka River near its confluence with the Nerch. ${ }^{1}$ This they succeeded in doing with some difficulty at the beginning of 1654. Lack of provisions, however, led to the threat of starvation, which was intensified by attacks from Buriats. After truce with the Buriats in the spring of 1655 , the Urazov detachment left the Shilka fort, which was burned the following year by a group of Tungus under the authority of the Evenk prince Gantimur. The immediate cause of this hostility has been attributed to raids on Gantimur's subjects by a group of fugitive Cossacks led by one Filka Poletai. ${ }^{2}$

The larger cause of native enmity toward Russians, however, appears to have been the reckless brutality inflicted upon aboriginal peoples by Erofei Khabarov, another of Russia's legendary seventeenth-century explorers and Cossack leaders. ${ }^{3}$ Although Khabarov is celebrated in the popular imagination as a national hero, his treatment of local tribes during the epic Amur River expedition of 1649-1653 was not only inhuman but violated Moscow's deliberate policy of conciliation toward the peoples of Siberia, a policy vital to the progress of Russian settlement and exploitation of the region. Indeed, Khabarov was stripped of his command by the tsar's emissary, Dmitrii Zinoviev, in August 1653, but the resentment - and attacks - continued for several more years.

The goal of a fortified settlement on the Shilka would not be deterred by the initial reverses. By command of tsar Aleksei Mikhalovich in June 1654, Afanasii Pashkov was designated the new voevoda of Dauriia, and by the beginning of the next year, the specific tasks of his command were defined by the Siberian Office (sibirskii prikaz). In the spring of 1656 Pashkov departed Yeniseisk on the arduous journey of over 2,000 kilometers, much of it by raft, to the Shilka River. ${ }^{4}$ Pashkov's accompanying group numbered some 420 (mostly sluzhilye liudi) and included as its priest the Old Believer dissenter archpriest Avvakum, with his family. (This remarkable choice shows that the Muscovite court, having sent Avvakum into harsh exile for his unrelenting opposition to Patriarch Nikon's ecclesiastical policies, still felt considerable sympathy for his person.) In his Zhitie (Vita) Avvakum gives a vivid and unflinching view of the rigors of the trip and often cruel discipline imposed by Pashkov. ${ }^{5}$

The passage itself took three years, much of it by river against the current. In the summer and fall of 1656, the group moved from Yeniseisk to the Bratsk fort, which provided shelter for the winter. In the spring of 1657 they continued in flatboats (doshchenik) up the Angara River to Lake Baikal, where Pashkov achieved the hazardous crossing by sail to the mouth of the Selenga River. ${ }^{6}$ By the fall of 1657, the detachment had reached the now ruined Lake Irgen fort, which Pashkov repaired for the winter. With little respite, Pashkov undertook a winter crossing in early 1658 from Lake Irgen to the Ingoda River, where 170 rafts (plot) were prepared for the group and its supplies. The final passage occurred in the spring and early summer of 1658 down the Ingoda and Shilka Rivers. ${ }^{7}$ Pashkov arrived at the mouth of 
the Nerch (and the ruins of Urazov's Neliudskii fort) in July1658.

Because of the scarcity of forests along the middle reaches of the Shilka, the logs for a new fort had already been cut during winter preparations on the Ingoda. (This was a not infrequent tactic in Siberian fort construction: cut the logs in an upriver location and float them down for rapid assembly at the designated site, so as to minimize the window of vulnerability during construction.) The Shilka-Neliudskii fort was quickly rebuilt on an island at the mouth of the Nerch, some five kilometers from the site of the earlier (1653) fort. ${ }^{8}$ The original walls were of sharpened, vertical logs, with four corner towers and an adjacent Church of the Resurrection. As early as 1659 the fort was referred to as "Nerchinsk" in state correspondence, although the previous names continued to be used by Pashkov himself. ${ }^{9}$

In any event Pashkov's days as voevoda in Dauriia were numbered, in large part due to tsar Aleksei Mikhailovich's anger at reports of a severe beating of Avvakum (72 strokes with the knout) at Pashkov's command in September 1656. Upon learning of this in 1658, the tsar promptly decided to remove Pashkov, yet various practical considerations delayed implementation of the decision for almost four years. The dramatic and endlessly complex psychological confrontation between Avvakum and Pashkov unfolded over a period of almost ten years, concluding in 1664 with Avvakum's complete victory over the repentant Pashkov shortly before his death in Moscow. ${ }^{10}$ It is an extraordinary gift of historical fate that Avvakum, one of the most distinctive writers in Russian letters and an exemplar of Russian religious dissent, should have been thrust into an expedition of such importance for maintaining the Russian presence in eastern Siberia. Although devoted primarily to the physical and spiritual trials inflicted on him and his family, Avvakum's account of the Pashkov expedition is an accurate and uniquely vivid description of the seventeenth-century passage to Siberia.

Avvakum was by no means the only member of the group to suffer the harsh discipline imposed by Pashkov. In his own report to the Siberian Office within a year of his arrival at the Nerch River, Pashkov noted that of the 300 enlisted men in the group, 58 had died, 6 escaped, and another 53 were ill.11 By the time L.B. Tolbuzin arrived in 1662 to assume duties as voevoda (through 1667) only 75 remained on active duty at all three Dauriia forts, including Irgensk; and by 1664 the number had dwindled to 46.12 Hunger and the difficulties in provisioning new fortified settlements over enormous distances proved major obstacles for Russian strategic moves toward the Amur River during the latter half of the seventeenth century. in view of this strategy, Russian authorities were inevitably burdened with the need for armed detachments in a strategic area with no mutually recognized borders.

As Aleksandr Artemev has written in regard to the Russian presence in Dauriia:

The tense situation, connected with constant raids by Mongol Taish tribes in the $1660 \mathrm{~s}-70$ s on Russian forts and on local tribute subjects of the Muscovite tsar, required the regular reinforcement of the Dauriia fort garrisons with sluzhilye liudi. Despite orders from the Siberian Office concerning assistance to the Nerchinsk region (uezd), the Yakutsk and Ilim voevodas were incapable of responding because of their own dearth of people. And in the enormous Yeniseisk territory, the voevoda for the same reasons annually sent only small parties of sluzhilye liudi. ${ }^{13}$

With the limited success of attempts to reinforce the Dauriia garrisons from Yeniseisk and other Siberian towns, Tolbuzin resorted to the unusual measure of accepting into the higher service category of sluzhilye liudi not only hunters and fishermen (guliashchie and promyshlennye liudi) but also non-Russian natives. ${ }^{14}$ 
The many serious obstacles notwithstanding, there were also favorable developments for Moscow in Dauriia. In 1667 the Evenk prince Gantimur, who had accepted Russian authority in 1655 and then turned against the Russians the following year, once again appeared at Nerchinsk with his extended family and servitors. Gantimur's rejection of the vassalage and protection of the recently established Manchu Qing (Ch'ing) dynasty led to an increase in tension along the Manchurian border. Not only did Gantimur control considerable territory near the Amur River, but his example was followed by other Evenk-Tungus leaders. ${ }^{15}$ Despite this serious affront to their authority, Chinese attempts to reclaim the now aged Gantimur were repeatedly foiled in 1669-1670 by the newly-appointed Nerchinsk voevoda, Danil Arshinskii, who also mollified Peking's resentment by suggesting that the "white tsar" wished to live in peace and friendship with Peking. ${ }^{16}$ The Russian policy of diplomatic deference and discreet maneuvering in the Amur region continued after Arshinskii's departure in 1673 as the Nerchinsk voevoda.

Diplomatic fencing could not, however, resolve the inevitable collision of Chinese and Russian interests in Dauriia. Having passed through Irkutsk and Nerchinsk in 1675, a major Muscovite embassy headed by Nikolai Spafarii reached Peking in 1676, but the ensuing negotiations failed to resolve the outstanding issues of territorial control and tribute levies. Although the Russian side refused to yield on the question of returning Gantimur, Peking was in a strong position to respond by blocking trade and by initiating military action, both of which eventually happened along the Amur River. Under the command of voevodas Petr Shulgin, Fedor Voeikov, and Ivan Vlasov (from 1684), Nerchinsk remained a forward command post for Russian responses to Chinese actions during the next decade. As the diplomatic situation reached an impasse, the Chinese campaign to expel the Russians from the Amur River basis focused on the Cossack fort of Albazin.

Albazin was an unusually dramatic example of Russia's violent "Wild East" during the seventeenth century. The first Russian mention of the settlement refers to events in 1650, when Erofei Khabarov, having seized the lands of a Daurian prince Albazy, wintered in Albazin and then burned it upon leaving in $1651 .{ }^{17}$ Despite this inauspicious beginning, the settlement's strategic location at the northernmost course of the Manchurian Amur, near its confluence with the Amuerkhe River, eventually attracted other Russians. The first major group, consisting of 84 Cossacks and peasants from the Ilim area, arrived in 1666. Their leader, Nikifor Chernigovskii, was a Polish exile in Russian service (sluzhilyi chelovek) who the preceding year had formed the group in rebellion against the wantonly cruel behavior of the Ilim voevoda, Lavrentii Obukhov.

It should be noted that the quality of Muscovy's representatives in Siberia, and particularly in distant eastern Siberia, varied greatly, from resourceful, intelligent leaders such as Arshkinskii to corrupt and debauched tyrants. In some cases, such as that of Afanasii Pashkov, courage and resourcefulness were combined with a propensity for harsh punishment in an era when such means were generally considered the only way to enforce discipline under circumstances of extreme hardship. In the popular imagination the voevodas were answerable only to God and the Tsar, but "God is on high, and the Tsar is far away." The Siberian Office exercised a system of control, especially through the Siberian "capital" of Tobolsk; but even when abuses were reported, redress frequently took two years, as couriers and investigators traversed a vast and difficult terrain.

The anger against Obukhov's misdeeds, which included numerous rapes, reached such intensity that he was killed during the uprising. 
Aware of the severe punishment for an attack on the tsar's representative, Chernigovskii's group undertook the long trek to the Amur borderlands beyond Moscow's control. Despite great distances, word of the Albazin area had spread within the network of Russian settlements in Siberia. Artemev notes the unexpected denouement to this bold move:

Once there they built a fort on the Albazin site and took upon themselves the functions of collecting tribute from the local population. The Cossacks punctually sent the collected tribute through Nerchinsk to Moscow. Meanwhile the tsarist administration had sentenced in absentia Chernigovskii and seventeen of his comrades to execution. However, the latter achieved such success in the collection of tribute, that in 1672 they were amnestied by an edict of the Siberian authorities [in Tobolsk]. ${ }^{18}$

Yet the Cossacks' very success in gathering tribute (such as valuable fur pelts) led to an escalation of local attacks on Albazin, as well as a Manchurian protest against this incursion into their own tributary system, a protest that led Arshinskii in 1670 to issue a ban on further tribute collection by the Albazin Cossacks.

A different tactic in strengthening the Albazin fort was tried by Petr Shulgin(Arshinskii's successor as Nerchinsk voevoda), who in the mid-1670s sent small groups of exiled peasants to till the rich land surrounding the post. This measure, too, would have fateful consequences in the following decade. In the meantime, the Albazin settlement took root, with a log Church of the Resurrection inside the stockade and a log chapel dedicated to Saint Nicholas at the outer defensive lines. ${ }^{19}$ By the early 1680 s the land produced grain sufficient not only for the needs of Albazin, but also for Nerchinsk. In a further irony this bounty - seemingly a godsend for the hard-pressed voevoda in Nerchinsk, Fedor Voeikov - set in motion events that the eastern Siberian authorities could not control. In the first place, word of the cornucopia began to attract settlers and fugitives from other parts of eastern
Siberia, so many, according to Artemev, that the central Amur River valley soon had more Russian settlers than the vast Transbaikal territory. ${ }^{20}$ And if the numbers were still relatively small, the movement nonetheless served as a portent on both sides of the border.

Russian authorities vacillated between attempts on the one hand to stem the flow to the Amur region (particularly of runaway peasants and deserters) and on the other to take the greatest advantage from the new settlements. In 1683 Prince Konstantin Shcherbatov, the super voevoda in Yeniseisk, coordinated a policy of reinforcing Russian settlements in Transbaikal and Dauriia, including the regions (uezd) of Irkutsk, Ilim, Iakutsk, Nerchinsk, and Albazin. ${ }^{21}$ Of these territories Albazin presented the greatest affront to Manchu authority, and demands were made for its evacuation. Thus, the settlement became a flash point for Russian armed resistance to Chinese attempts to reassert their control over the Amur. After sharp fighting in June 1685 the Albazin commander, Aleksei Tolbuzin, was compelled to surrender the fort (which was then burned) and return to Nerchinsk, together with the few hundred surviving Cossacks and peasants.

Surprisingly, the Nerchinsk voevoda, Ivan Vlasov, not only permitted the peasants to return to the Albazin site in August to harvest the spring grain but also commanded the rapid rebuilding of the fort under the direction of Aleksei Tolbuzin. In proportions that indicate the primarily military purpose of this move, the contingent included 448 service men, 70 peasants, and 96 hunters and craftsmen. ${ }^{22}$ Subsequent reinforcements brought the number of Russian to over 800 by late June 1686. This active response to a recent defeat and a Manchu ultimatum led to a final siege, formally lasting from the beginning of July until the end of November 1686. Despite the overwhelming superiority of forces on the Chinese side 
(including over 6,000 troops and a siege tower with cannons manned by twenty Dutch Jesuits) and the death of Tolbuzin five days into the siege, the Russian garrison successfully resisted all attempts to storm the fort.

Moscow in the meantime had decided to make the best of an untenable situation and sent Fedor Golovin as a plenipotentiary to negotiate an end to the conflict. When this news reached Peking in late November, the Chinese attempted to end the siege, but the frozen Amur River blocked the movement of their own forces, which retreated a short distance from the fort. As a result, both sides suffered substantial losses from hunger and cold. When the Chinese finally withdrew in the fall of 1687 , only a few dozen soldiers remained under the command of lieutenant Afanasii Beiton. Scores of the Russian dead remained in a log hut, unburied, for lack of a priest. ${ }^{23}$

During the diplomatic maneuvering after the stalemate at Albazin, Moscow proposed that the Amur River serve as a boundary between the two states and China countered with a demand to surrender not only Albazin but Nerchinsk as well. With increasing pressure on the de facto Muscovite ruler, the regent Sophia, following the failure of Russian campaigns in the Crimea in 1687 and 1689, Moscow's emissary accepted a Chinese compromise. ${ }^{24}$ The Russians were compelled to surrender Albazin, and within days of the signing of the Treaty of Nerchinsk (August $29,1689)$ the Russian garrison survivors razed the fort under the eyes of the Chinese and retreated to Nerchinsk. Apart from archeological remnants, there are no visible traces of the early Albazin settlement, Nerchinsk, however, survived as a Russian possession, and with its favorable location near the Shilka River the settlement became one of the most important centers for administration and trade with the Manchu empire. ${ }^{25}$ The eighteenth century town was built almost entirely of logs, although two masonry churches arose at the beginning of the century: the Cathedral of the Trinity (1720; not extant) and the Church of the Dormition at the NerchinskDormition Monastery, founded by order of tsar Peter I (subsequently the Great) in 1706 on the site of the original Cossack post created by Maksim Urasov in 1653. The monastery's first church was built of logs in 1710, and the brick Church of the Dormition followed soon thereafter, in 1712 (Fig. 1). Although the Church of the Miraculous Icon of the Savior in Irkutsk was completed slightly earlier, the Nerchinsk Dormition Church is nonetheless one of the oldest Russian masonry churches in Siberia, particularly in the Far East. ${ }^{26}$ In view of the difficulties in marshalling material and technical support for masonry construction anywhere in Siberia, the presence of two brick churches in such a distant part of Russia is clearly

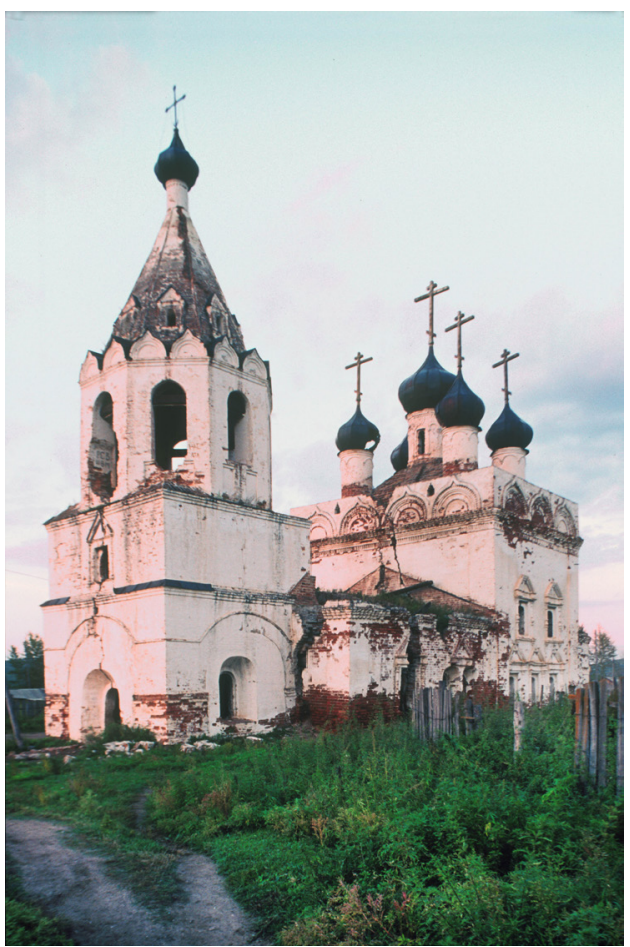

Fig. 1. Kalinino. Cathedral of the Dormition, Nerchinsk Dormition Monastery. Southwest view. Photograph: William Brumfield (9/12/2000) 
the result of political priorities (defined by the tsar himself) in stating the Russian presence in this strategic area, near the border of the Qing empire.

There is no known documentary evidence about the origins of the builders of the Dormition Church, and its design - a simple cuboid structure with five cupolas, a vestibule, and a bell tower over the west entrance - seems more archaic than that of contemporary masonry churches in Siberia and the Urals, despite window pediments that show traces of Ural-Siberian motifs. ${ }^{27}$ At least one specialist has linked the Nerchinsk church to late seventeenth-century architecture of the Russian north, a reasonable assumption in view of the origins of many of Siberia's Russian builders and explorers in towns such as Velikii Ustiug. ${ }^{28}$ Indeed, the area along the Northern Dvina River contains a number of examples, such as the Church of Saint Barbara (1693-1702) at Ukhtostrov, similar to the Dormition Church at Nerchinsk. The bell tower, in the traditional octagon-over-square form, is the most skillfully realized component, with its own cupola above a small drum.

In 1812 Nerchinsk was relocated to ground north of the confluence of the Nercha and Shilka Rivers in order to escape periodic floods. ${ }^{29}$ From that time the use of masonry construction increased for both secular and religious structures. The dominant structure of the first half of the nineteenth century was the Cathedral of the Resurrection, begun in 1814 and completed in $1841 . .^{30}$ The cathedral, never completed to its first plans, provided by Irkutsk, now exists in a disfigured state, including the loss of its bell tower (Fig. 2). But even the cathedral's original design represented a curious reversal of the usual Russian Orthodox form, which places the sanctuary in the major structure at the east end. In this case, however, the sanctuary was contained within an octagonal component of two small stories, engulfed by side altar chapels of larger floor space. It is possible that the region's severe climate recommended this distribution of space to the lower side altars as a way of conserving heat while accommodating the number of worshippers expected in the town's main church during long winters.

During the nineteenth century Nerchinsk endeavored to maintain a position as one of the main points for trade with the Orient. ${ }^{31}$ This mercantile side of the town was visibly represented by its imposing Merchants' Court (gostinyi dvor), whose graceful neoclassical design possessed a sense of proportion lacking in the cathedral, which it faces on the same axis. The center of the Merchants' Court, completed in 1840, consists of a two-story building with an arcaded ground floor supporting a portico of six doric columns and a pediment (Fig. 3). The main structure is flanked on either side by low elongated extensions that were divided into a total of twenty stalls for commercial space. ${ }^{32}$ These extensions originally had an arcade providing access to the trading stalls, and although the arcade has since been enclosed, its outlines are still visible on the facade. The main structure's evocation of a temple of commerce is a device that appeared in Merchants' courts throughout the Russian provinces, yet the Nerchinsk example shows more care in overall design as well as

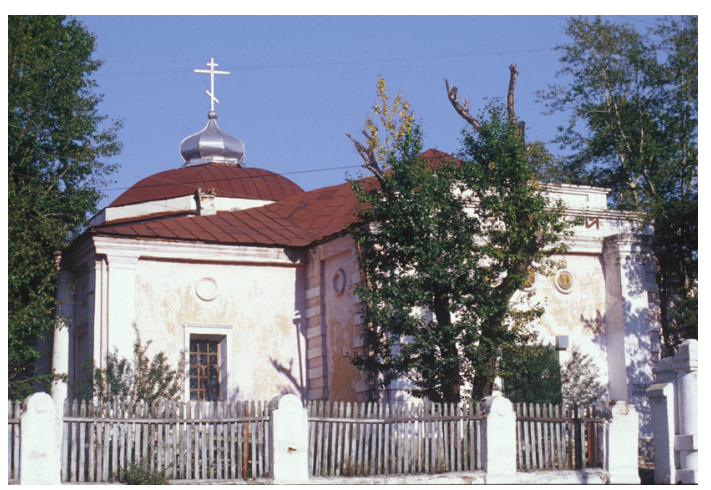

Fig. 2. Nerchinsk. Cathedral of the Resurrection. West view. Photograph: William Brumfield (9/12/2000) 


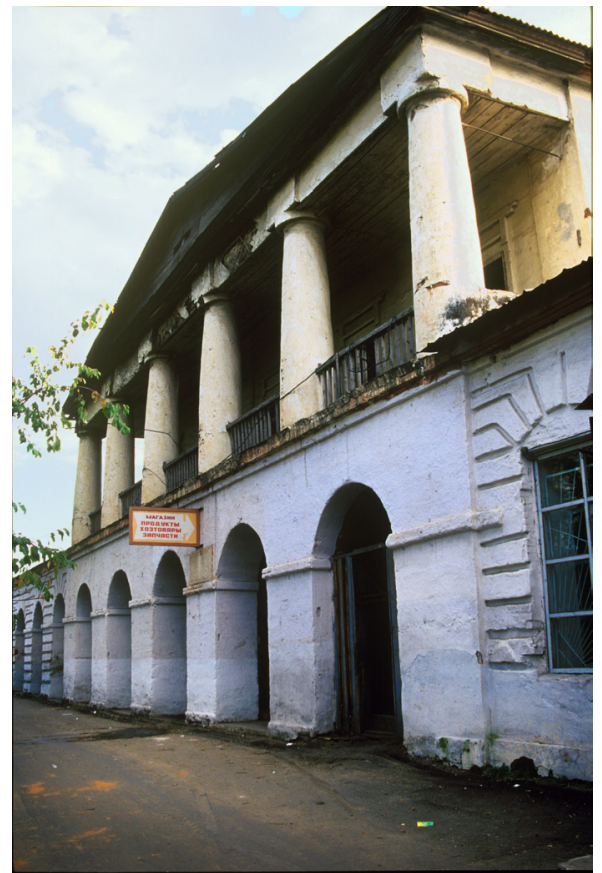

Fig. 3. Nerchinsk. Gostinyi dvor (Merchants' Court). Photograph: William Brumfield (9/12/2000)

detail, particularly when compared with the Gostinyi dvor in Kiakhta.

After the suppression of the Decembrist uprising in 1825, Nerchinsk, and the Nerchinsk silver mines, gained wide notoriety as the place of incarceration for a number of the exiled nobles. ${ }^{33}$ This dubious distinction was not, however, without its benefits for the town, which, like Irkutsk, gained from the education and enlightened culture of the Decembrists, most of whom were gradually allowed to resettle in more favorable conditions. ${ }^{34}$ Furthermore, after the reforms of the reign of Alexander II, the economic development of Siberia accelerated, and Nerchinsk, well placed on the Shilka River, temporarily benefitted from these changes.

One of the most revealing examples of this economic growth in the Trans-Baikal area is represented by the merchant Mikhail Butin (18361907), co-founder of a family enterprise that in many ways reinvigorated Nerchinsk during the latter half of the nineteenth century. Indeed, the mansion and attached store (Fig. 4) that he built transformed the appearance of the town's center, as will be noted below. In his own substantial book on Siberia, Mikhail Butin wrote that he was descended from a prospector sent to the Nerchinsk area at the turn of eighteenth century by Peter I as part of an expedition in search of valuable ores. ${ }^{35}$ By the beginning of the nineteenth century the great-grandsons of the first Siberian Butin had built a substantial local trade in furs, which they sold primarily at the fair in Nizhnii Novgorod. The family capital continued to be passed down to successive generations, yet narrow inheritance laws restricted access to that capital by younger progeny. ${ }^{36}$

In response to their confining financial situation, the brothers Nikolai and Mikhail Butin moved to Kiakhta, where the former began transporting tea from Kiakhta to Nerchinsk for the merchant Nikolai Khrisanfovich Kandinskii (1810-63), great-uncle of the renowned modern artist Vasilii (Wassily) Vasilevich Kandinskii (1866-1944). Indeed, the extended Kandinskii family had arrived in Siberia even earlier than the Butins. Evidence indicates the presence of Kandinskiis (or Kondinskiis) in Tomsk during the seventeenth century. Wassily Kandinskii's great-

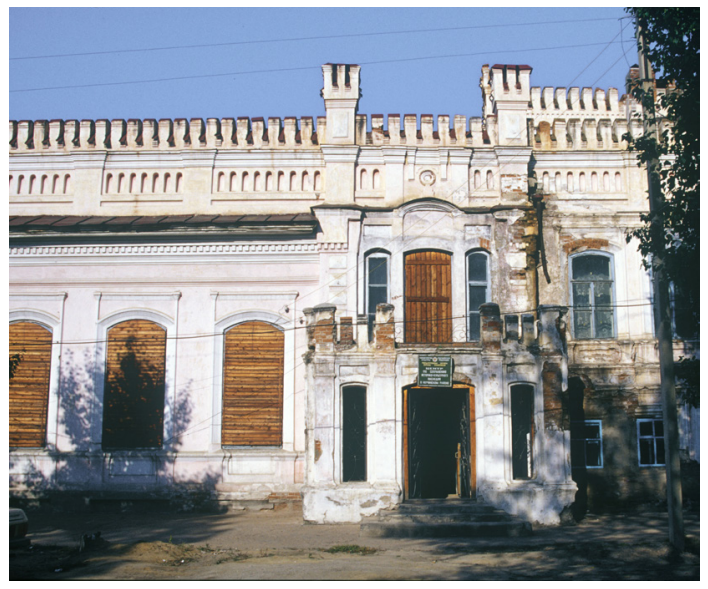

Fig. 4. Nerchinsk. M.D. Butin mansion. West façade. Photograph: William Brumfield (9/12/2000) 
great-grandfather, Petr Alekseevich Kandinskii (1735-96), was exiled to Nerchinsk (apparently for church theft in Yakutsk) after 1752. His son Khrisanf Petrovich Kandinskii (1774-1850s) continued the father's larcenous ways and was condemned to penal servitude in the Nerchinsk area. ${ }^{37}$ Upon release in the early nineteenth century, however, Khrisanf became a model citizen and highly successful entrepreneur, who is known to have made substantial donations for the construction of two churches at the Kandinskii estate village of Biankino, on the Shilka downriver from Nerchinsk. ${ }^{38}$

One of Khrisanf Kandinskii's sons, Silvestr (1794-1869), had a son Vasilii (1832-1926), who was the father of the great artist. Although Vasilii Silvestrovich Kandinskii was himself well known as a tea merchant in Kiakhta-Troitskosavsk, his wealth allowed him to travel widely. In 1862 he met the leading Russian political exile and thinker Alexander Herzen in London, and shortly thereafter he settled in Moscow, where the future genius of modern art was born in 1866.39 Another of Khrisanf Kandinskii's sons, Nikolai, was the tea trader for whom Nikolai Butin worked. Despite his move to Moscow in the 1850s, Khrisanf Kandinskii continued to be involved in the tea trade and in his Troitskosavsk stores, for which Nikolai Butin had become the managing director. ${ }^{40}$

The preceding genealogical excursus is intended to provide an insight into the intricate web of entrepreneurial connections created by a few Siberian dynasties, a web that extended from the Russian Far East to the merchant elite of Moscow. The success of Nikolai Butin in the firm of Nikolai Kandinskii not only enabled Butin to provide employment in the Kandinskii stores for his younger brother Mikhail, but also gave the two brothers an inside advantage in buying the Troitskosavsk firm after the death of Nikolai Kandinskii in 1863. Following this purchase the Butin brothers moved the merchandise and equipment to Nerchinsk (at that time about 4,000 inhabitants), where in 1866 they opened a large emporium known as Torgovyi dom brat'ev Butinykh (Trading House of the Butin Brothers). ${ }^{41}$

The operations of the Butin enterprise, unprecedented for this region in scale and quality, soon reached far beyond Nerchinsk. In the words of one Siberian historian: "Already by the end of the 1860s the Butins had concentrated in their hands a retail trade that stretched from the shores of the Pacific Ocean to the banks of the Enisei..." ${ }^{\text {"42 }}$ But the Butins' ambitions were not limited to retail trade. For almost fifteen years following the establishment of the Butin firm, the pace of their acquisitions and investments mounted at a vertiginous rate: the technologically advanced Novo-Aleksandrovskii distillery near Irkutsk in 1871; the Nikolaevskii iron foundry near Bratsk in 1872; and another distillery and salt works in the 1870 s. To serve these far-flung enterprises, the firm maintained a number of river boats. ${ }^{43}$

In the midst of this expansion Mikhail Butin also found time to equip and accompany serious expeditions such the one to China in $1871 .{ }^{44}$ Although possessed of only a few grades of primary schooling, Mikhail Butin was a remarkable autodidact, and in the same year as his China trip he published a small book, A Historical Sketch of Relations between the Russians and China, with specific recommendations for the improvement of trade and transportation between Russia and China. He noted with concern the rapid expansion of trade between China and European powers, while Russia remained limited by the tea trade along an old and difficult trading route through Kiatkhta and central Mongolia to Peking. Butin recommended a more direct route from Nerchinsk through the tip of eastern Mongolia south to Peking and the port of Tientsin: "This route will increase our market in Mongolia and Manchuria, will decrease the cost of transport 
from China of Chinese and other countries' goods. Furthermore, it will serve as a means for the spread of Russian influence on the population of those localities with whom we will need to enter into close acquaintance, and all this will happen peacefully, in the name of civilization and progress. ${ }^{945}$ In reality Butin's views were ahead of his times, and Russian expansion in this area over the next three decades would prove fraught with difficult and dangerous complexities, particularly in view of growing Japanese designs in the area. Nonetheless, Butin's vision of a new route bore some relation to the eventual path of the Russiansponsored Chinese Eastern Railway in the 1890s. ${ }^{46}$

The Butin firm also held a major interest in the Darasun gold mines, as well as others acquired along the Amur River. ${ }^{47}$ The productivity of these works improved significantly as a result of technological measures introduced after Mikhail Butin's trip across the United States in 1872. Butin was profoundly impressed by what he saw in America, both in a positive sense and in contrast to the lagging economic development in Siberia. The importance of the American model in his mind is demonstrated by his publication of a small book on the trip soon after his return. Entitled Letters from America, the volume gave numerous examples of American initiative in opening trading routes and markets throughout the Pacific Basin, not excluding Russia's Far Eastern territories. Although amicable in tone, the text expresses the concern of a Siberian entrepreneur over the American advance at Russia's expense. ${ }^{48}$

Like American entrepreneurs, Butin placed particular importance on the necessity of an active program of railroad construction:

Only the extension of the railway along the entire length of our Siberian territory can create the solid colonization of our interior provinces. Indeed, the more we remain uninvolved spectators of political and economic events taking place in the vicinity of our eastern fringes, the worse the situation of things will become for us. ${ }^{49}$
Butin's was by no means the only contemporary voice raised in support of a trans-Siberian railroad, yet this vast undertaking did not formally begin until two decades later, in 1891.

Mikhail Butin was generous with his wealth, which directly supported a number of institutions in Nerchinsk: a telegraph station in 1867, a public library and the Saint Sophia Women's School (in memory of his wife) in 1868, a free public music school, a printing house, pharmacies, and primary schools for nearby villages. ${ }^{50}$ The clearest architectural expression of his enormous energy, however, was the brick mansion that he constructed next to the company's headquarters in the center of Nerchinsk. Built and lavishly furnished in the late 1870 s, this mercantile "palace" is eclectic in style, although the gothic revival predominates through details such as the crenelation above the cornice. (see Fig. 4) Did Butin choose this style in expression of some distant spiritual kinship to the mercantile dynasties of Renaissance Italy? Perhaps the use of crenelation was a suitably imposing expression of his wealth and benevolent power within the community.

Whatever the impression created by the exterior, the extent of wealth and luxury was far more evident in the grand rooms of the interior. Although almost all of the mansion's interior was ultimately pilfered or vandalized, particularly after the 1917 revolution, Butin's Xanadu continues to exist in a detailed, admiring description by George Kennan, the distinguished American traveller, social activist, and pioneer of Russian studies. Kennan had arrived in Nerchinsk in late November 1885 as part of his extensive - indeed, for an American unprecedented - research travels for his epochal book Siberia and the Exile System. Part of the mansion's impact on Kennan can be explained by the sheer improbability of its existence in 
so remote and difficult a part of Siberia, not far from the notorious Nerchinsk mines. The effect was increased still further after a miserable night spent by Kennan and his colleague George Frost at a hotel ("the very worst hotel that we had seen in Siberia") run by a Polish exile identified only as Klementovich. ${ }^{51}$

With a letter of introduction provided by Mikhail Butin, now living in Irkutsk for reasons that will be explained below, Kennan's description of the mansion still conveys the vivid sense of surprise that will be familiar to anyone who has traveled extensively in Siberia:

Going into it from Klementovich's hotel was like going into Aladdin's palace from an EastSiberian étape [prisoner forwarding station - WB]:

[A]nd as I entered the splendid ball-room and caught the full-length reflection of my figure in the largest mirror in the world, I felt like rubbing my eyes to make sure that I was awake. One does not expect to find in the wilds of Eastern Siberia, nearly 5000 miles from St. Petersburg, a superb private residence with hardwood marquetry floors, silken curtains, hangings of delicate tapestry, stained-glass windows, splendid chandeliers, soft Oriental rugs, white-and-gold furniture upholstered with satin, old Flemish paintings, marble statues, family portraits from the skilful brush of Makofski, and an extensive conservatory filled with palms, lemon-trees, and rare orchids from the tropics. Such luxury would excite no remark in a wealthy and populous European city; but in the snowy wilderness of the Trans-Baikal, 3,000 miles from the boundaryline of Europe, it comes to the unprepared traveler with the shock of a complete surprise. ... It seemed to me that I had rarely seen more evidences of wealth, refinement, and cultivated taste than were to be found within its walls. ${ }^{52}$

Kennan, who had ample opportunity to see glittering interiors in America, could be an unsparing, acerbic critic of Russian life. His admiration of the Butin mansion, however, was unfeigned. The greatest praise was reserved for the main public rooms:

The ball-room, which was the largest room in the house, was about sixty-five feet in length by forty-five in width, and over it, in a large semicircular gallery reached by a grand stairway, there was an orchestrion, as big as a church organ, which played sixty or seventy airs and furnished music for the entertainments that the Butins, in the days of their prosperity, were accustomed to give to the people of the town. The library, which was another spacious apartment, was filled with well-selected books, newspapers, and magazines, in three or four languages, and contained also a large collection of Siberian minerals and ores. Adjoining the house were the offices and shops where the Butins carried on the various branches of their extensive and diversified business, and where they had accumulated the wealth that the house partly represented or embodied. ${ }^{53}$

By the time George Kennan visited the Butin mansion, the Butins themselves were no longer in residence. Through a series of natural disasters and other reverses, their heavily leveraged firm had begun to unravel in 1879. Attacked by creditors and competitors in Irkutsk at a time of economic depression in Siberia, the Butins felt compelled to agree in 1882 to a courtappointed administration that proceeded to strip the firm of assets. ${ }^{54}$ While Nikolai Butin stayed in Nerchinsk to defend the company's interests there, Mikhail moved to Irkutsk in 1884 to follow the court proceedings and to maintain important commercial contacts. Indeed, Kennan and Frost had met Mikhail Butin in Irkutsk several weeks before their arrival in Nerchinsk. Kennan described Butin as someone "who had traveled extensively in the United Sates and who was half an American in his ideas and sympathies". 55

Butin eventually prevailed in 1892 to regain control of his firm, yet administrative mismanagement during the intervening ten years left only a shell with large debts. (The temporary administrators had, of course, paid themselves large fees at the expense of the firm.) Exhausted by the strain of constant legal and financial disputes, Nikolai Butin died in September 1892, at which point Mikhail Butin dismantled most of the company to cover debts. ${ }^{56}$ The mansion was transferred to the Nerchinsk city administration. With the sale of his remaining profitable metalworking factories in 1896, Mikhail Butin 
devoted himself to writing, philanthropy, and social causes in Irkutsk, where he died in 1907.

Although the visions that the Butins had for the development of eastern Siberia, the entrepreneurial spirit that emanated from their company is still evident in the compound that they built in Nerchinsk. In a pattern typical of Muscovite family commercial enterprises, office and warehouse buildings were grouped adjacent to the residence, which occupied a dominant position at the intersection of two main streets. ${ }^{57}$ Originally, the main facade of the residence was linked by a high brick wall and grand neoclassical archway (not extant) to the warehouse office, which contained an elaborately decorated twostory brick water tower (Fig. 5). The Butin compound possessed a general stylistic unity, with its white stuccoed walls and brick ornament culminating in crenelation along the cornices.

Notwithstanding the eclectic, historicist style of the Butin compound, the center of Nerchinsk is suffused with a provincial neoclassical ambience that one might associate with certain regional towns of the United States in the middle of the nineteenth century. The defining component of the neoclassical ensemble is the Merchants' Court (see Fig. 3), overlooking Bazaar Square. Its columnated center is reflected in two other

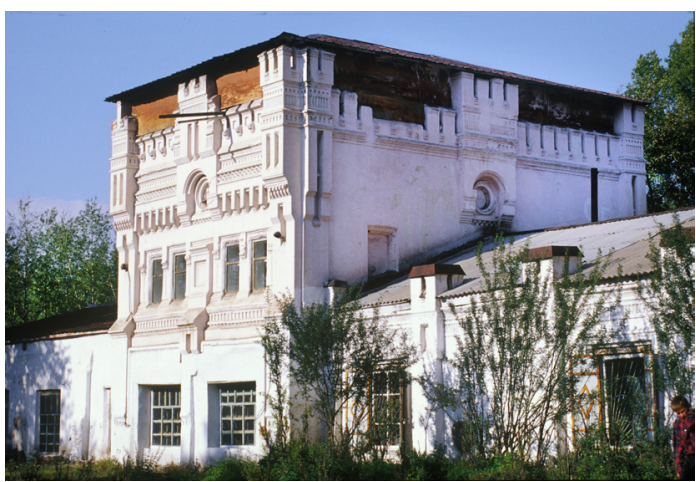

Fig. 5. Nerchinsk. Water tower and warehouse, M.D. Butin compound. Photograph: William Brumfield $(9 / 12 / 2000)$

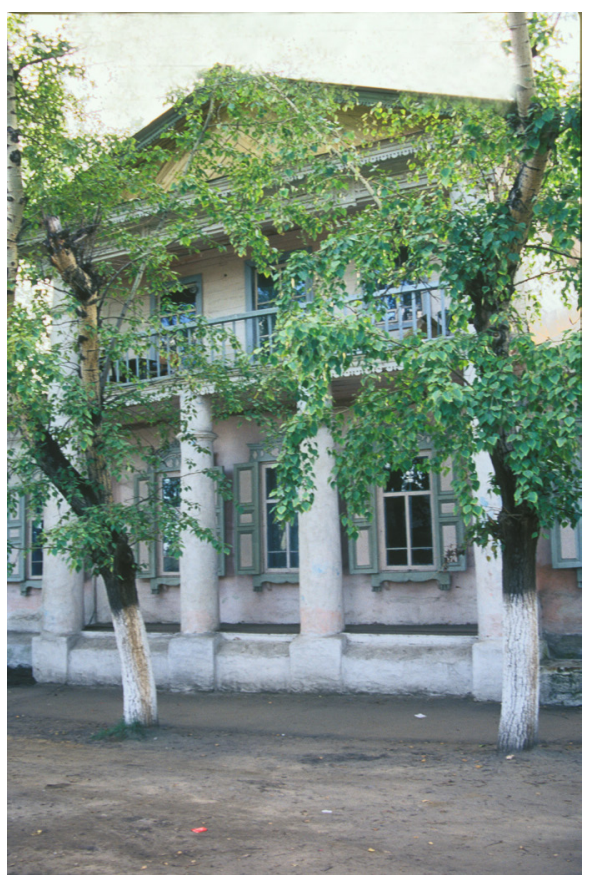

Fig. 6. Nerchinsk. Hotel Dauria. Photograph: William Brumfield (9/12/2000)

buildings in the vicinity of the square: the Hotel Dauriia (Fig. 6) and the main pharmacy. Built during the second half of the nineteenth century, both the hotel and the pharmacy are essentially one-story structures with an elevated center (known in Russian as mezzonin). The pediment of the mezzonin rests on two Doric columns that frame a balcony supported by two smaller columns. This simple but effective transformation provides a grace note to the center of nineteenthcentury Nerchinsk.

It is not clear whether the Hotel Dauriia is the one that so irritated George Kennan in 1885, but local lore has it that Anton Chekhov stayed in the hotel in June 1890, five years after Kennan's visit. Although Chekhov had not yet achieved immortality as a playwright, he was already an immensely popular writer of short stories. Encouraged by friends such as the publisher Aleksei Suvorin and spurred by an awareness of the evil of the forced exile system, Chekhov embarked in April 1890 on a trip across Siberia 
to reach Sakhalin Island, with its notorious penal colony. The ensuing work, Sakhalin Island (1893-94), would become an exposé not only of the island's penal administration but also of the lugubrious effects generally of Russian colonization in the Far East. ${ }^{58}$

Chekhov's journey also resulted in a shorter account, From Siberia, devoted to Siberia proper, with its mixture of natural grandeur and extreme living conditions. Consisting primarily of impressions from the road for Suvorin's newspaper, Novoe vremia, Chekhov's account, like Kennan's much longer work, frequently uses incidental details to show the pervasive effect of the exile system in Siberia. Chekhov did not, however, fulfill his original intention to describe the entire trip across Siberia. ${ }^{59}$ Demanding travel conditions beyond Irkutsk prevented the writing of dispatches, and his primary goal was Sakhalin Island. Therefore, the historic town of Nerchinsk, and its hotel, did not appear in his published work on Siberia. Nerchinsk does, however, have laconic mention in Chekhov's correspondence with his family: "Yesterday was in Nerchinsk. Not a knockout of a town, but livable." ${ }^{\prime 60}$

Although the waning of the tea trade had weakened the development of Nerchinsk, the town's location near a major river and the TransSiberian Railway sustained a modest level of prosperity evident not only at the Butin compound, but also in other substantial commercial buildings erected toward the end of the nineteenth century (Fig. 7). Nerchinsk also had attractive wooden houses, usually of one story, with elaborately ornamental window surrounds and cornices typical of Siberian architecture at the turn of the twentieth century (Fig. 8, 9, 10). ${ }^{61}$ In some cases these dwellings are connected to a small store (Fig. 11). Nerchinsk is now a dusty provincial town with a declining population of less than 16,000; yet the historic core reminds of a century in which it witnessed Anton Chekhov, George

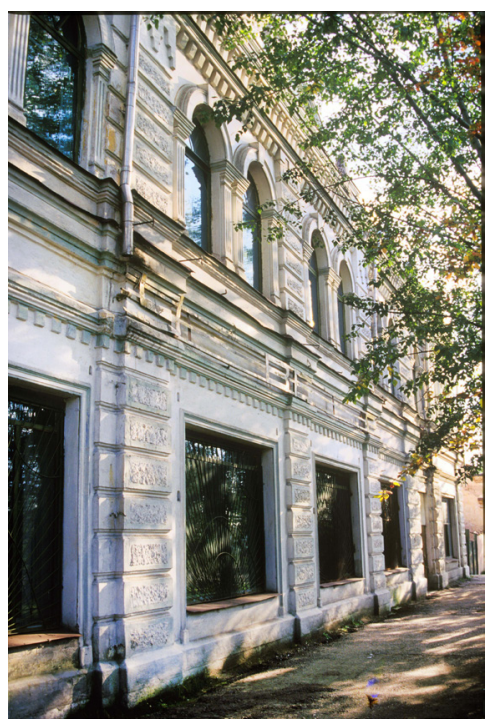

Fig. 7. Nerchinsk. Butin Department Store, Shilov Street 4. Photograph: William Brumfield (9/12/2000)

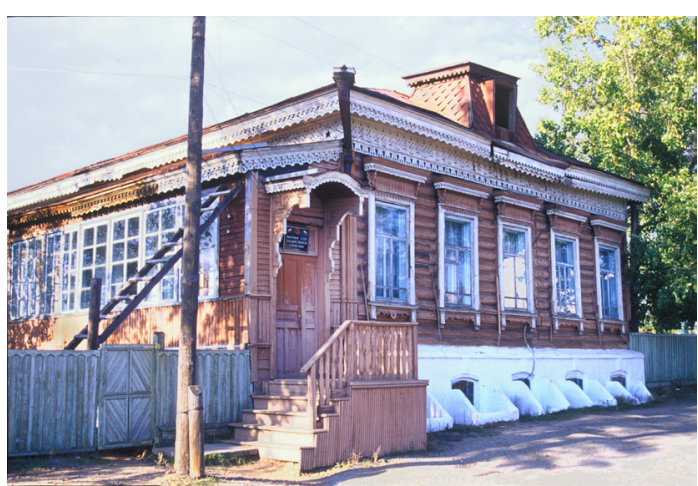

Fig. 8. Nerchinsk. Wooden house, Shilov Street 15. Photograph: William Brumfield (9/12/2000)

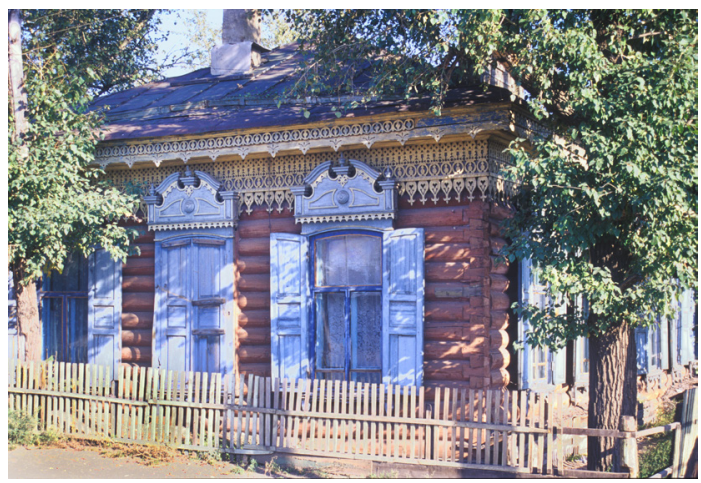

Fig. 9. Nerchinsk. Wooden house, Soviet Street 22. Photograph: William Brumfield (9/12/2000) 


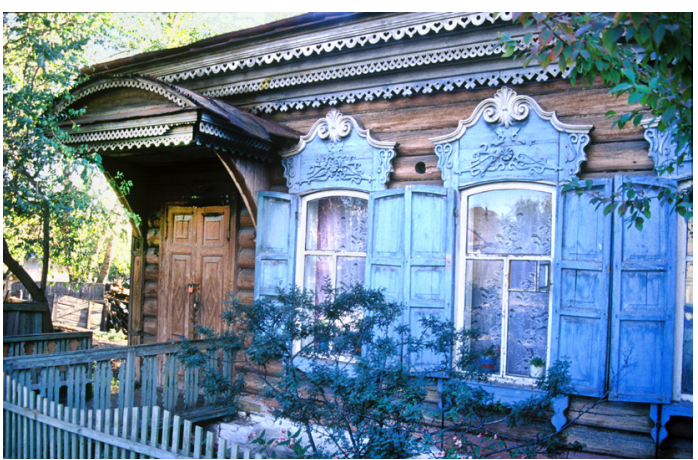

Fig. 10. Nerchinsk. Wooden house, May First Street 22. Photograph: William Brumfield (9/12/2000)

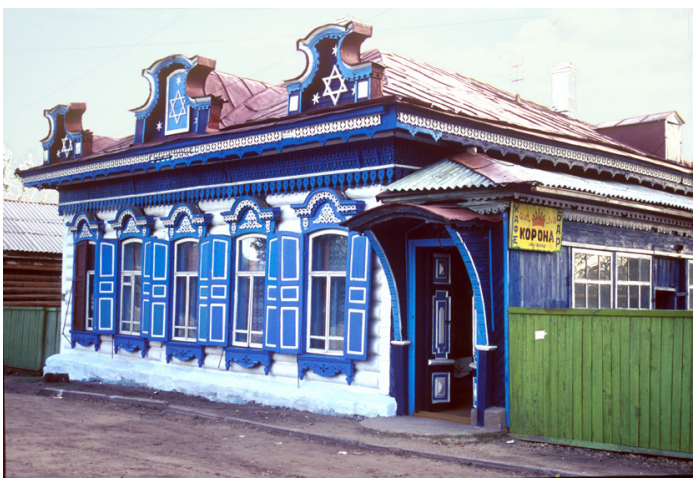

Fig. 11. Nerchinsk. Wooden house and store, Soviet Street 12. Photograph: William Brumfield (9/12/2000)

Kennan, Vasilii Kandinskii's merchant ancestors, and, for that matter, Mikhail Butin, the "Siberian American".

Even as Nerchinsk drifted into provincial torpor, Chita to the west assumed a major role in Russia's Far Eastern expansion at the turn of the twentieth century. Located at the confluence of the Chita and Ingoda Rivers, the site of contemporary Chita attracted the attention of the noted Siberian explorer Petr Beketov, who made an Ingoda winter post (zimovye) there in 1653. Although the first permanent settlement, called Sloboda, was established in the late $1670 \mathrm{~s}$, the post, renamed Chitinskaia sloboda in 1687, grew very slowly. During the 1690s a few Cossacks, trappers, and fishermen were resettled to Chitinskaia sloboda. Their presence, however, offered little impetus for commercial development, and the Chita settlement remained a secondary link in the administrative and transportation system within Dauriia. ${ }^{62}$

Chita's one notable landmark from the eighteenth century, the log Church of Archangel Michael, was originally built in 1705 , shortly after the Chita settlement was elevated to the status of "fort" (ostrog). After a fire the church was apparently rebuilt in 1771, and then again in $1775 .{ }^{63}$ Its patron was one Evgenii Gurkin, a merchant from distant Solvychegodsk in the far north of European Russia. (Northern merchants were frequently pioneers in the development of trade in Siberia, the Far East, and even Russian America.) The Archangel Michael Church (Fig. 12) exemplifies traditional wooden Orthodox architecture, with a central cuboid structure, a large polygonal apse in the east, and a vestibule and octagonal bell tower in the west. The central structure culminates in an octagonal drum and low dome. The form is thoroughly traditional, without the soaring tower forms that distinguish

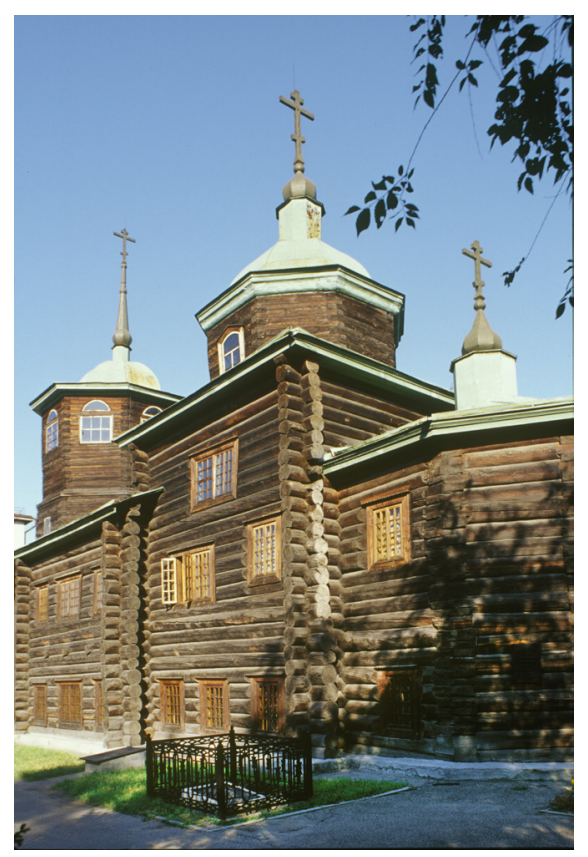

Fig. 12. Chita. Church of Archangel Michael. Southeast view. Photograph: William Brumfield (9/14/2000) 
northern Russian log churches. ${ }^{64}$ Ironically, the church's excellent state of preservation is due in no small part to its reputation as "the church of the Decembrists," a reference to the Chita exile of some two dozen participants in the failed uprising against Nicholas I in December 1825. During the Soviet era the church was converted into a museum devoted to the Decembrists and their exile in the Chita area, a function that it maintains to this day. ${ }^{65}$

Indeed, for many observers Chita during the nineteenth century became identified with Siberian exile culture, particularly after 1851, when Chita became the administrative center of the Transbaikal Territory (Zabailkal'sksaia oblast') and headquarters of the Transbaikal Cossack Troops. In his Siberia and the Exile System, George Kennan described meetings in the fall of 1885 with Chita's political exiles, whom he sees as the moral inheritors of the Decembrist legacy. ${ }^{66}$ Their plight and the situation of those in nearby penal colonies and mines produced a deeply disturbing impression on Kennan. ${ }^{67}$

With the arrival of the Trans-Siberian Railway in Chita in 1900, the town experienced a substantial increase in building, which further accelerated with the completion of the Chinese Eastern Railway in 1903. The latter railroad, negotiated as part of an 1896 defense treaty with the weakened Chinese, allowed the Russians much shorter access, across Manchuria, to Vladivostok and surrounding territories along the Ussuri River. ${ }^{68}$ As the nearest major settlement to the junction of the Chinese Eastern Railway with the still uncompleted Trans-Siberian, Chita seemed perfectly situated to play a commanding role in Russian designs on the Far East. Photographic views of the town at the beginning of the twentieth century show large masonry buildings, often with art nouveau decorative flourishes, arising out of an expanse of dark Siberian muck (Fig. 13). ${ }^{69}$ If the population of Chita in 1900 was approximately 12,000 , Baedeker gives the population in 1914 as 73,000, an extraordinary rate of growth driven by railroad expansion. ${ }^{70}$

Although most of the streets of Chita were renamed in the Soviet era, the central part of the city retains a grid plan extending to the north of the railroad, which runs parallel to the westeast course of the Chita River. The drawback to this arrangement is the railroad's separation of the central district from the river (Irkutsk and Krasnoiarsk are more fortunate in this regard), but the railroad was clearly the town's dominant presence, and the street pattern reflects this. The original station building, constructed in 18991903, was symmetrical in design and middling in size, with Beaux Arts and classicizing details (Fig. 14).

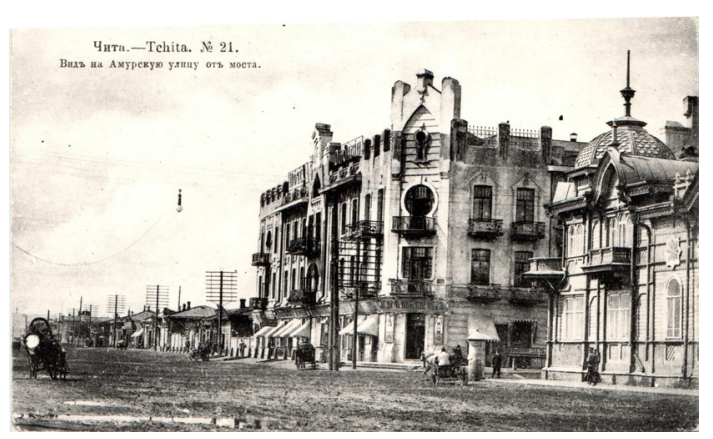

Fig. 13. Chita. View of Amur Street with Hotel Dauria. Early 20th-century postcard

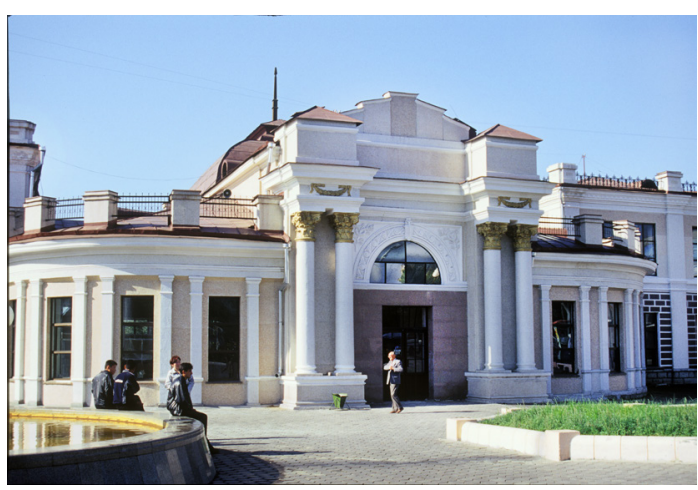

Fig. 14. Chita. Railway Station. Photograph: William Brumfield (9/14/2000) 
This rapid growth was not without the turbulence that afflicted Russia generally at the beginning of the twentieth century. As has been noted, the Nerchinsk-Chita area had long been used as a place of exile, and with the development of the railroad, the area acquired a substantial number of skilled workers, many of whom were not sympathetically disposed to the existing political and economic order. Following a series of military failures in the Russo-Japanese War and triggered by the massacre of demonstrators in Saint Petersburg in January 1905 ("Bloody Sunday"), many areas of the country witnessed an outbreak of strikes and even armed rebellion. In Chita this uprising culminated in a short-lived "Chita Republic," which lasted from December 1905 to January 22, 1906. After offering some concessions toward greater political and religious freedom, the tsarist regime used military force to restore authority throughout the country in the aftermath of this "First Russian Revolution." In Siberia and the Far East the punitive campaign, including the execution of most of the leaders of the "Chita Republic," 71 was supervised by Baron Alexander Meller-Zakomelskii and General Paul von Rennenkampf, the latter notable for his lack of military success in both the Russo-Japanese and First World Wars.

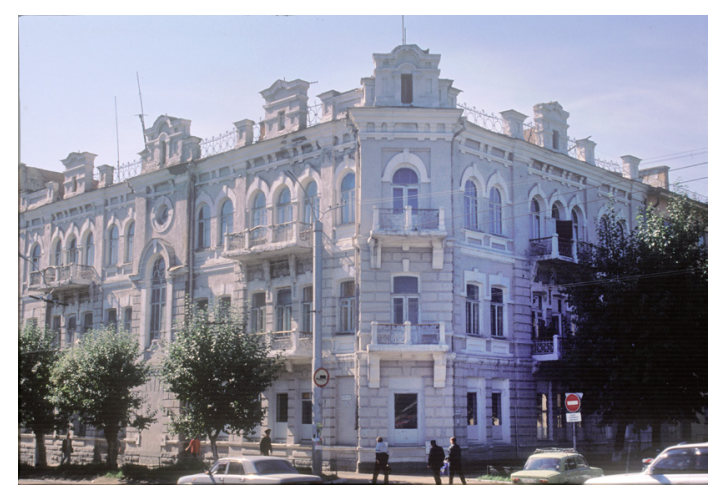

Fig. 15. Chita. K.I. Bulemakin building, Butin Street 22. Photograph: William Brumfield (9/14/2000)
Chita, like other Siberian centers, seemed to recover quickly from the disorders of 190506 , and several multi-storied masonry buildings arose over the following decade. Indeed, the architecture of central Chita is still defined by these large early twentieth-century structures. Some of them were clearly intended to suggest the decorative architectural styles of Russia's major cities. Such is the case with the eclectic K.I. Bulemakin Building (1907-11; Fig. 15) and the Beaux Arts style Shumov Building (1913-15; Fig. 16), both reminiscent of Saint Petersburg apartment and commercial buildings at the end of the nineteenth century. ${ }^{72}$ The Shumov brothers, who made their money in trade and gold mining, erected a lavish monument to urban prosperity, with an elaborate cornice and large decorative bays. As the most imposing building in town, it was appropriated by the NKVD in 1937 (the year of the Great Purges) and has served its successor security organizations ever since.

As in Petersburg, these large buildings were usually surfaced with stucco, but some were designed to exploit the decorative properties of red brick. A good example of Chita's "brick style" was the building constructed in 1902 for Vasilii Khlynovskii, who at the time served as mayor. Designed by Gavriil Nikitin, the building initially contained the Hotel Moskva, and from

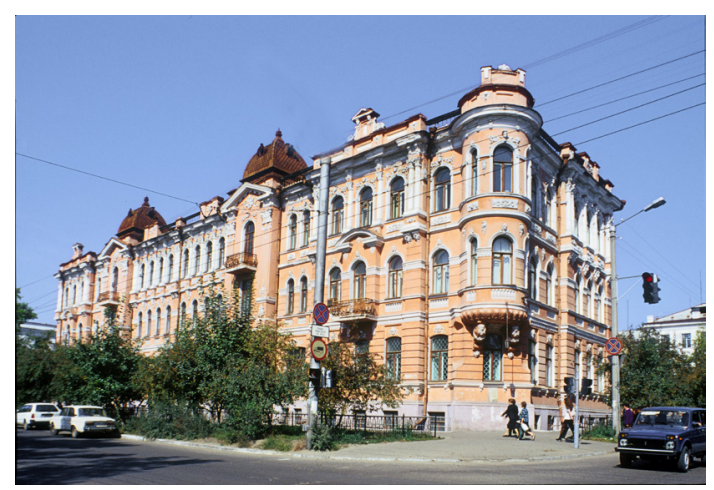

Fig. 16. Chita. Shumov Building, Lenin Street 84 . Photograph: William Brumfield (9/14/2000) 


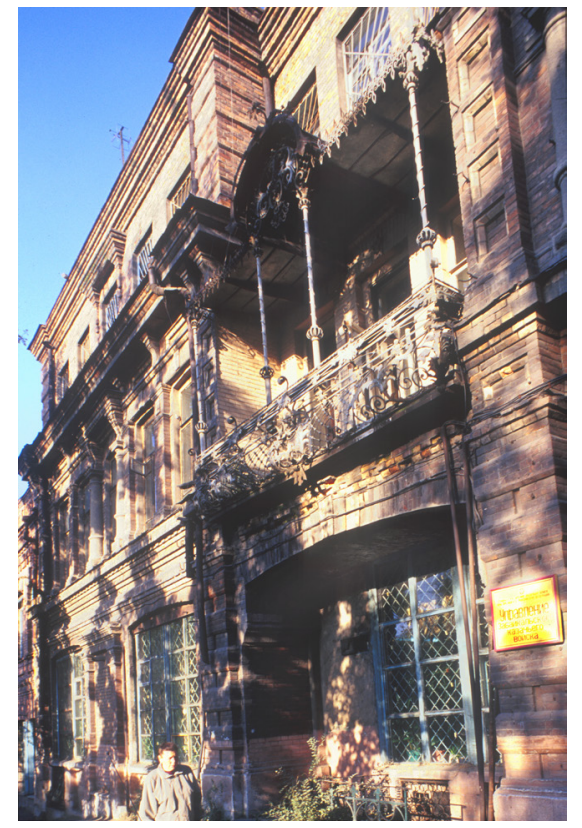

Fig. 17. Chita. B.V. Khlynovskii Building. Photograph: William Brumfield (9/14/2000)

1906-12 served as the Russo-Chinese Bank. The most distinctive feature of the Khlynovskii Building's facade was its twin cast-iron balconies (more accurately, loggias), with a dominant heraldic motif of eagle and dragons (Fig. 17). During the Soviet era the building's complex cornice was flattened and another story added, but the phantasmagoric ironwork still flanks a large central window, with its baroque pediment above the second story.

Not all commercial buildings in Chita followed conservative eclectic styles. Chita was a young city on the frontier of Russia's future in Asia, and its commercial architecture on occasion strove to embody a sense of modernity. The evolution of the contemporary look is evident in a row of buildings constructed for A. E. Dukhoi between 1907 and 1911 (Fig. 18), with more eclectic decorative detail in the earlier buildings and a "modernized," Viennese Secession-style treatment of detail in the final building (Fig. 19). ${ }^{73}$ More obvious examples of the "style moderne," as modern commercial architecture was generally called in Moscow and Saint Petersburg, are the Zazovskii Building (1909-11: Fig. 20) and a three-story building commissioned by Dmitrii V. Polutov, yet another
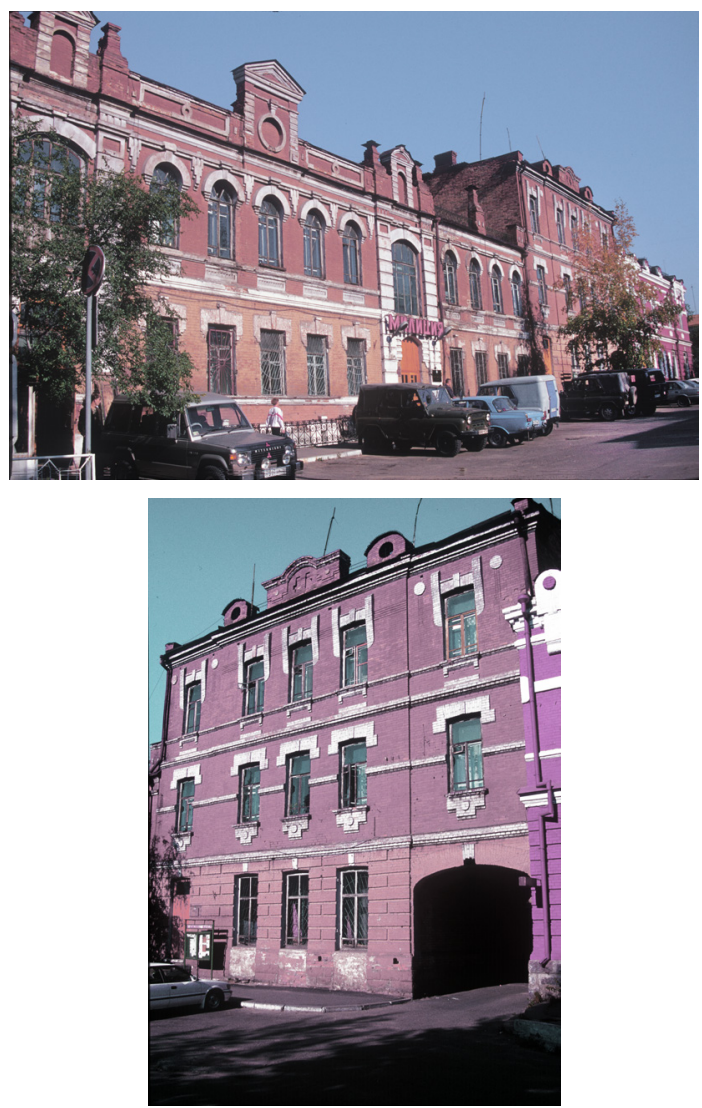

Fig. 18. Chita. A.E. Dukhoi Building, Nerchinsk Street 19. Photograph: William Brumfield (9/14/2000)

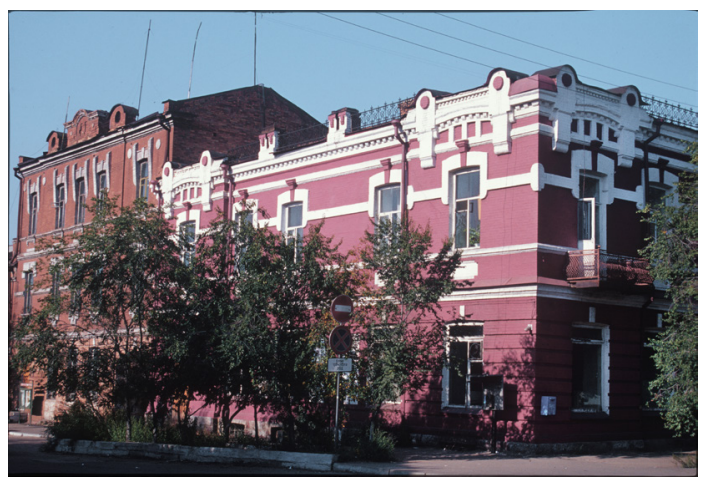

Fig. 19. Chita. A.E. Dukhoi Building, Nerchinsk Street 21. Photograph: William Brumfield (9/14/2000) 


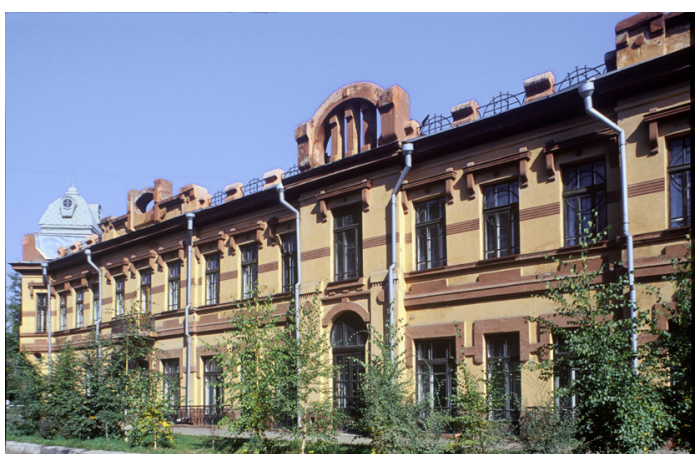

Fig. 20. Chita. Zazovskii Building, Anokhin Street 56. Photograph: William Brumfield (9/14/2000)

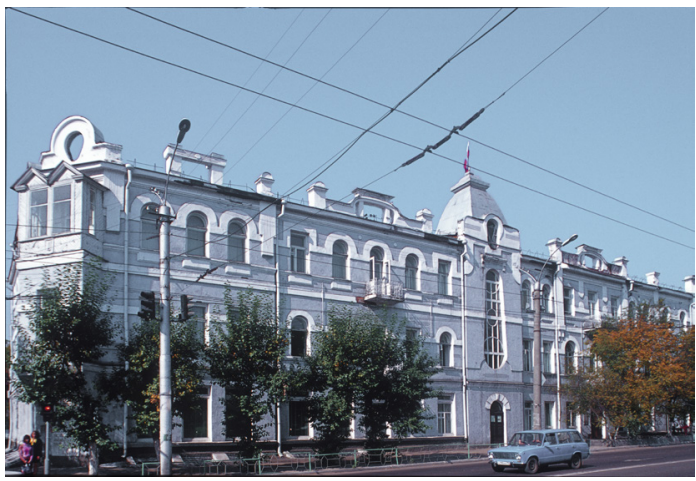

Fig. 21. Chita. Dmitrii V. Polutov Building, Butin Street 39. Photograph: William Brumfield (9/14/2000)

wealthy Siberian entrepreneur whose fortune was based on trade and gold mining. Located on Cathedral Square across from the main Chita post office, the original part of the Polutov building was completed in 1908, with an expansion to its current size (Fig. 21) in 1914. A subsequent building belonging to Aleksandr V. Polutov (1910; Fig. 22) was designed by Fedor Ponomarev with a more elegant combination of style moderne with Beaux Arts detail.

The most advanced, "rational" approach to commercial architecture in Chita appeared in the design for a department store and office building owned by the large Siberian retail firm of Vtorov. The patriarch of the family, Aleksandr Fedorovich Vtorov, began as a textile entrepreneur in the central Russian city of Kostroma, on the Volga

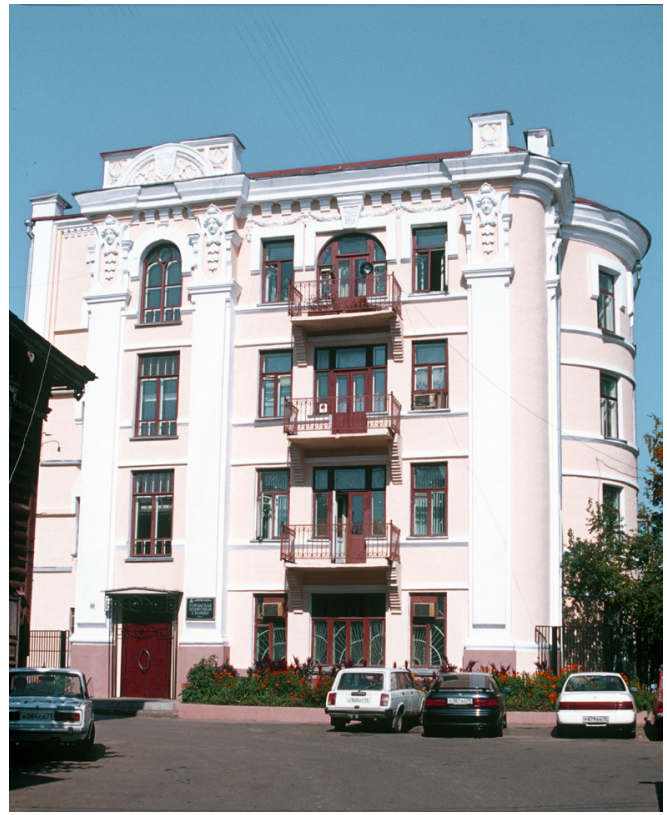

Fig. 22. Chita. Aleksandr V. Polutov Building, Lenin Street 100B. Photograph: William Brumfield (9/14/2000)

River, and subsequently developed a fortune from selling textiles in Siberia during the latter half of the nineteenth century. From their base in Irkutsk, the Vtorov firm expanded throughout eastern Siberia (including Tomsk, Verkhneudinsk, and Troitskosavsk) and by the end of the century they had also established a major commercial and financial presence in Moscow, where the firm developed an advanced, rationalist style of commercial architecture. ${ }^{74}$

In Chita the Vtorov Building (1911-12; Fig. 23) follows a similar style largely devoid of historicist decorative detail, although like most large buildings on corner lots in Chita, it had a rounded corner surmounted with a turret. The overall design, however, shows a clearly defined structural grid, surfaced with high-quality glazed white tiles. The facade's ample fenestration, culminating above the cornice in a Palladian thermal window (semicircular, divided into three lights by two vertical mullions), not only provides ample natural light for the office space but also 
proclaims the aesthetic values of modernity. This crisp, refined integration of structure and ornament suggests architectural design on a

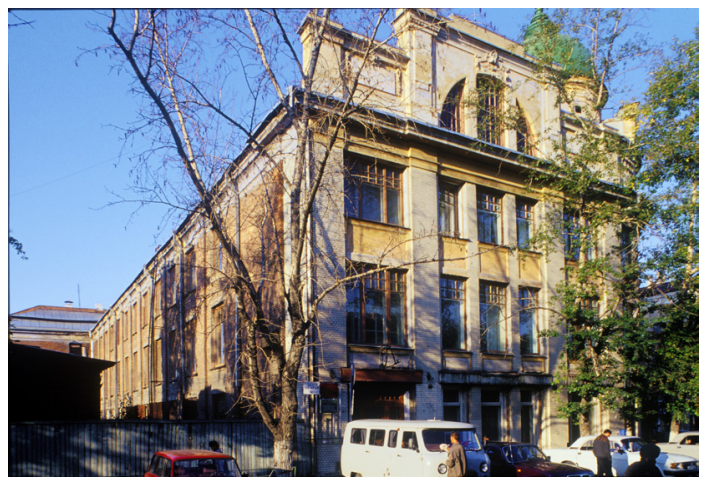

Fig. 23. Chita. Vtorov Building (Passage), Amur Street 56. Photograph: William Brumfield (9/14/2000)

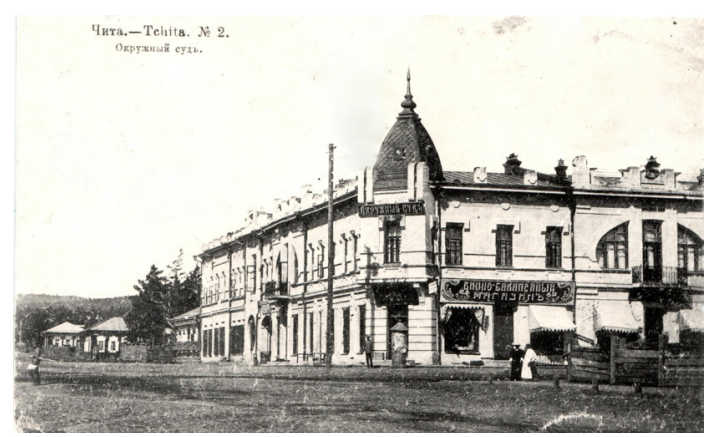

Fig. 24. Chita. Starnovskii Building. Early 20thcentury postcard

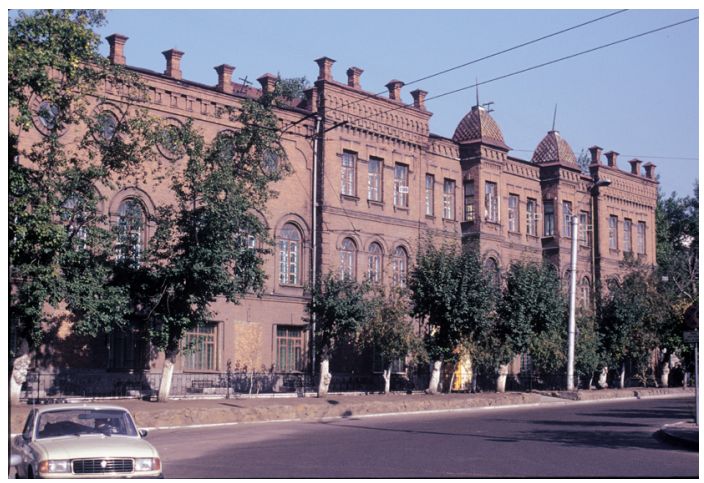

Fig. 25. Chita. Command Headquarters of TransBaikal Cossack Troops and General Office of the Amur Railway, Ataman Square. Photograph: William Brumfield (9/14/2000) major urban level and is commensurate with the Vtorov firm's reputation as an economic force in Moscow, as well as in Russia generally.

Certain commercial buildings in Chita combined retail operations with space for government administrative offices. For example, the Regional Court (okruzhnyi sud) rented space in a building owned by Ignatii Starnovskii, a merchant of Polish origins. Designed by Fedor Ponomarev and completed in 1907, the Starnovskii building offers a medley of decorative touches, but its most noticeable feature is its exaggerated art nouveau windows on the second story (Fig. 24). The first floor was occupied by retail enterprises such as a wineshop. An even closer merging of administrative and commercial interests characterized the City Council Building, built in 1906-07 by Liutsian (Lucian) Drevnovskii, a wealthy contractor (also of Polish origins) from Irkutsk. The city council (duma) occupied the upper floor and rented the ground floor to commercial tenants, thus increasing the duma budget.

The largest administrative building in Chita was built for the command of Trans-Baikal Cossack Troops on Ataman Square. Completed in 1910, this sprawling red brick edifice combined the neo-Romanesque with Italianate fortress details on the cornice (Fig. 25). It served both as Cossack headquarters and as the general office of the Amur Railway (part of the TransSiberian), which at that point was undergoing a major expansion from Nerchinsk to Khabarovsk. Space in the building was also rented for a hotel, a restaurant, and the Rekord Cinema.

A few government entities were located in wooden buildings, such as the Central Post Office (1893; Fig. 26), situated three blocks from the main railroad station. In view of the widespread demolition of historic buildings in Russian cities, it is little short of miraculous that this building not only remains standing, but still serves its 


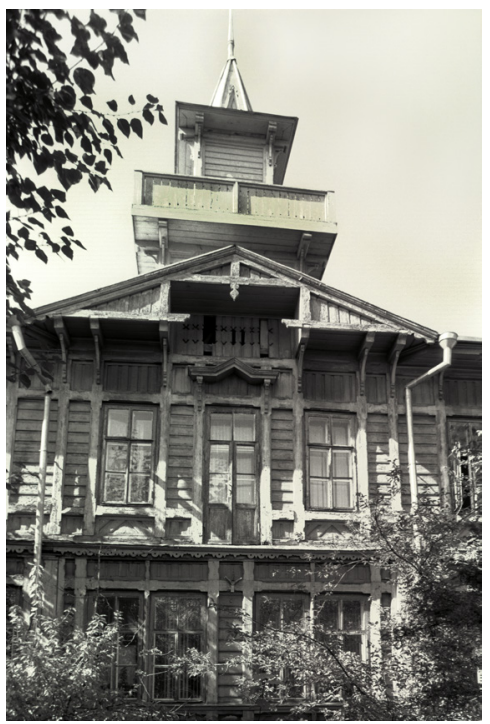

Fig. 26. Chita. Post Office and Telegraph Building. Photograph: William Brumfield (9/14/2000)

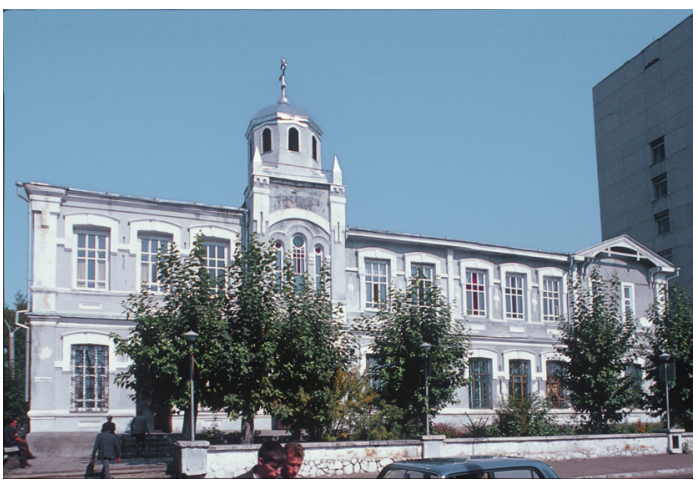

Fig. 27. Chita. Orthodox Missionary School, Butin Street 12. Photograph: William Brumfield (9/14/2000)

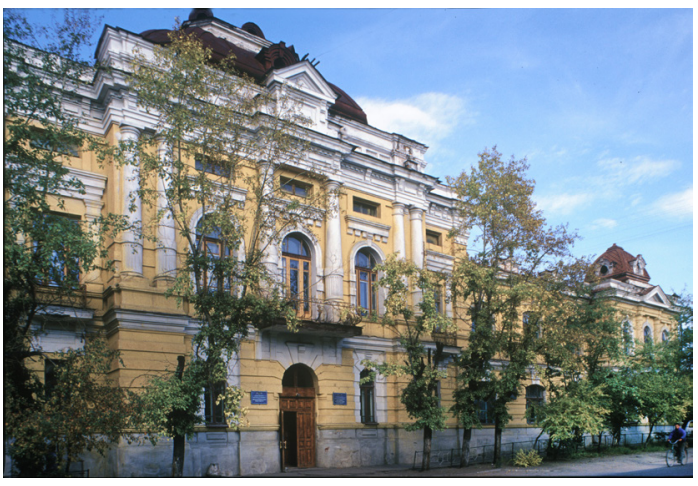

Fig. 28. Chita. First Women's High School, Chkalov Street 140. Photograph: William Brumfield (9/14/2000) original purpose. The wide, two-story structure displays a panoply of ornament in the globespanning decorative style of late nineteenthcentury wooden architecture.

Educational institutions followed more conservative tendencies in architectural style, such as the Orthodox Missionary School (1889; Fig. 27), whose simplicity derives from modest means and a relatively early date of construction. More imposing in both scale and execution is the First Women's High School (gimnaziia), designed by Gavriil Nikitin and built in 1907-09 (Fig. 28). This grand manner, drawn from a Beaux Arts style transmitted through the Russian capitals, was used at the beginning of the twentieth century for elite schools in several Siberian cities, where such buildings proclaimed a local pride in comprehensive education for women as well as men.

In comparison with older urban centers along the main route to Siberia, Chita had few significant examples of church architecture. The eighteenth-century log Church of the Archangel Michael is by far the oldest surviving religious structure in the city. The middle of the nineteenth century witnessed the completion of a wooden eparchal cathedral, and in 1899 the foundation was laid for a masonry cathedral, dedicated to Saint Alexander Nevskii. Construction of this ponderous structure, built of brick in the neoByzantine style, continued until 1909 (Fig. 29). In 1936 the cathedral was demolished and its brick used for the construction of a school and a military administrative building. Indeed, so ruthless was the Soviet destruction of Russian Orthodox churches in Chita, that from 1944 the one remaining active Orthodox parish met in a wooden church originally built in 1851 for a Catholic parish and expanded at the turn of the twentieth century (Fig. 30). ${ }^{75}$ In 2001 work began on a new Orthodox cathedral, dedicated to the Kazan Icon of the Mother of God. 
Despite the destruction visited upon Chita's Orthodox heritage, some churches in the area survived, such as the active Church of Saints Peter and Paul, built in 1904 at Shilka. Located some 250 kilometers to the east of Chita, the settlement was founded near the Shilka River in 1899 as a station on the Trans-Siberian Railroad. The Church of Saints Peter and Paul (Fig. 31) is one of the rare surviving examples of a standardized project for wooden churches adjacent to railroad stations in Siberia. Nicholas II took a special interest in the providing of churches (and, in this case, an adjoining parish house and priest's residence) for new communities not yet able to afford the expense of such buildings. The structure's milled siding, placed in prefabricated panels for ease of

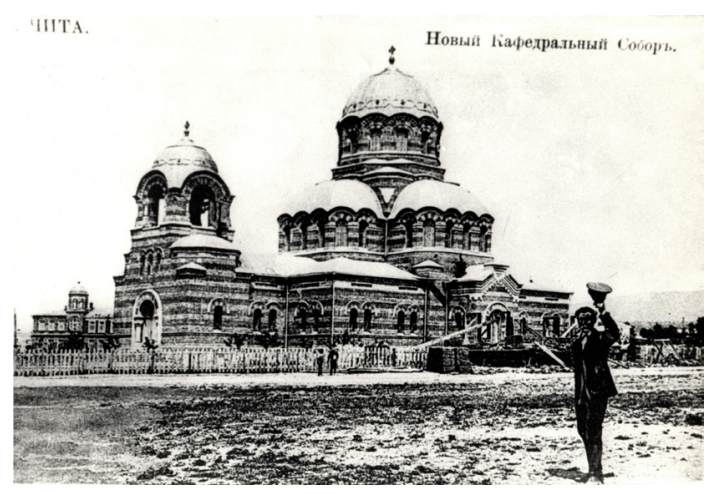

Fig. 29. Chita. Cathedral of St. Alexander Nevskii. South view. Early 20th-century postcard

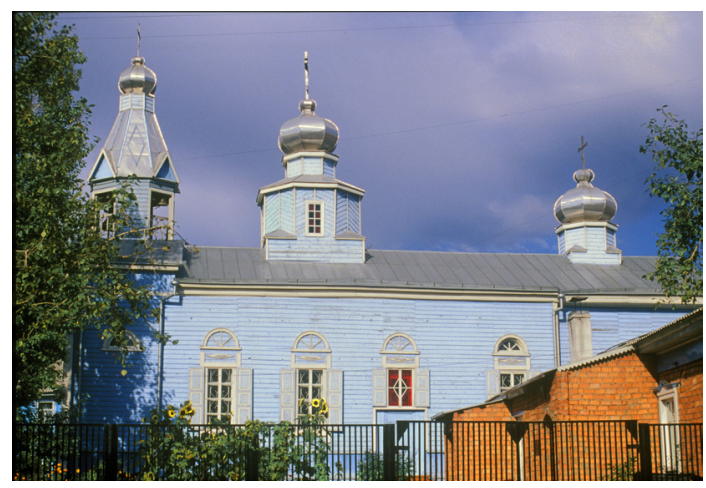

Fig. 30. Chita. Church of the Resurrection. Photograph: William Brumfield (9/14/2000)

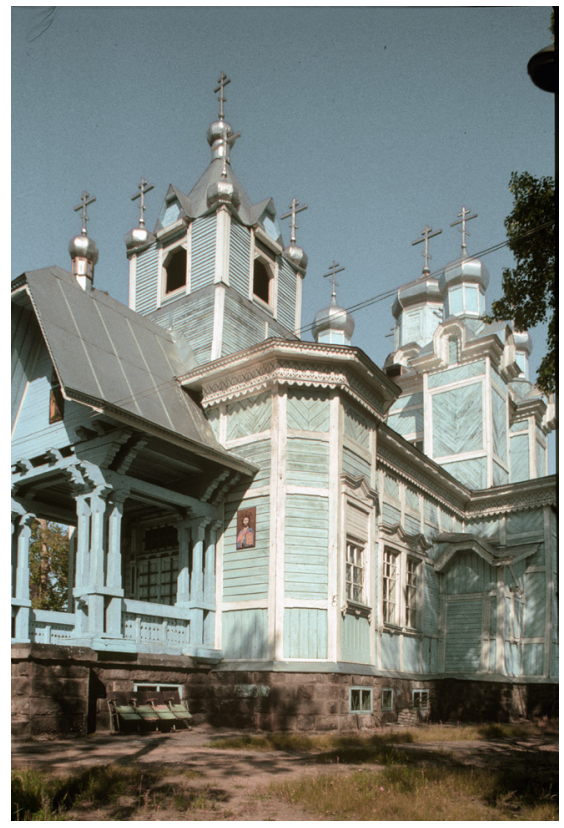

Fig. 31. Shilka. Church of Sts. Peter and Paul. Southwest view. Photograph: William Brumfield (9/12/2000)

transportation and construction, serves as a base for ornamental window frames and cornices. Metal cupolas arise not only above the main worship space but also over the bell tower, the vestibule, and the entrance porch. A curious, but no less effective decorative element is provided by the large crossed beams that support the porch roof - an approach suggestive of Asian temple architecture.

But within Chita itself, evidence of prerevolutionary Russian Orthodox architecture has survived only in photographs and documents. Indeed, Chita's largest surviving house of worship built before the revolution is the synagogue (Fig. 32), one of the most imposing in Siberia upon completion in 1907. The final design, by Iakov Rodiukov, combined "Moorish" and romanesque elements typical of Russian provincial synagogues. In 1930 the synagogue was closed and adapted to use by a variety of institutions, including, most recently, a clinic. Although its dome was removed, the monumental form of the synagogue is a testament not only 


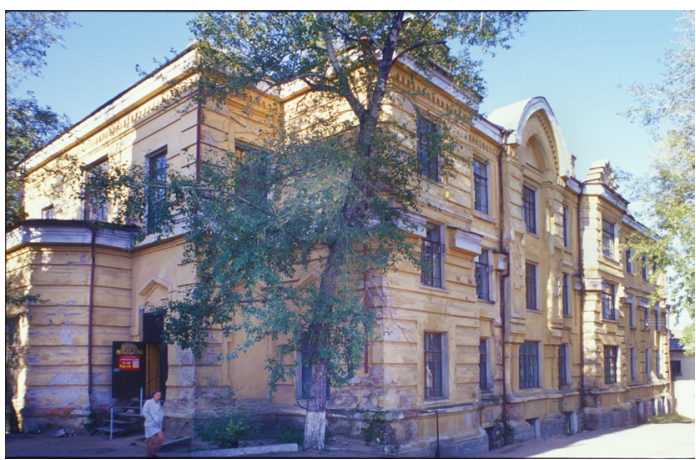

Fig. 32. Chita. Synagogue. Northeast view. Photograph: William Brumfield (9/14/2000)

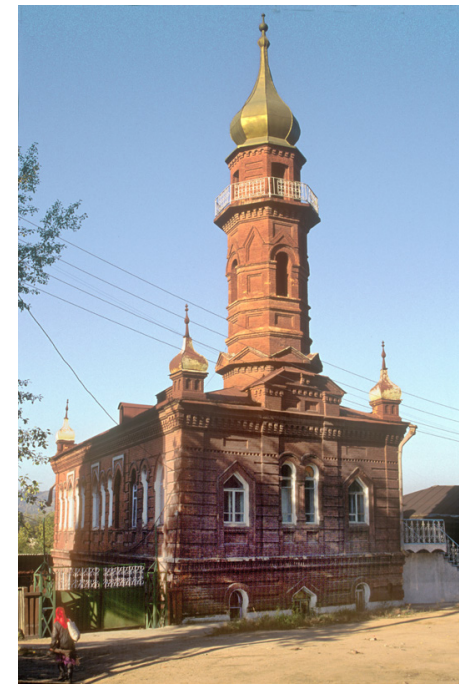

Fig. 33. Chita. Mosque, Anokhin Street 3. Photograph: William Brumfield (9/14/2000)

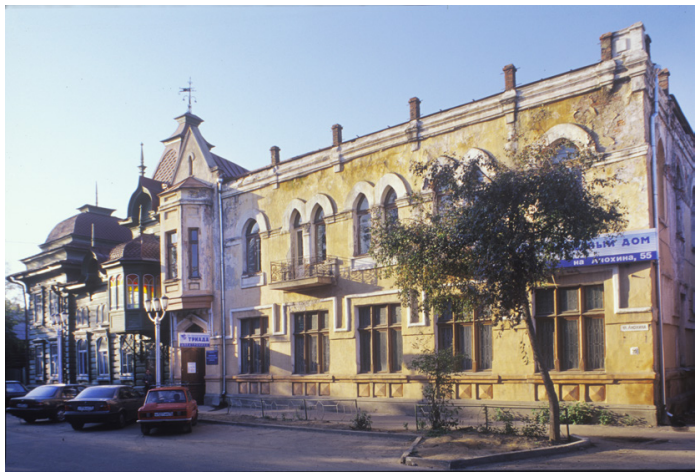

Fig. 34. Chita. M.D. Ignat'eva house (left), RussoChinese Bank. Photograph: William Brumfield $(9 / 14 / 2000)$ to the relatively tolerant attitude of Siberian officialdom toward non-Orthodox religious communities but even more to the significant presence of the Jewish community in Chita. Through its direct investment, its entrepreneurial activity, and its prominent position in the building trades, the Jewish community in effect built much of prerevolutionary Chita within a remarkably brief period.

Among other prominent communities was the Tatar population, whose main mosque was built in 1904-06 (Fig. 33). The red brick structure, with corbelled cornice brackets, serves as a base for a minaret that culminates in a tall metal cupola. In addition to the mosque, the building also housed a school and charitable society. Early twentieth-century panoramas of Chita also show a large Buddhist temple, but it did not survive in the Soviet era.

If religious and commercial structures defined the center of Chita, the city also experienced a rapid growth in private houses during the few decades before the revolution. Wood was the primary building material, even for large residences such as the M.D. Ignatyeva house, located next to the Gothic revival Russo-Chinese Bank (Fig. 34). In this wellpreserved example of a Siberian mansion, turrets, domes, bay windows and decorative window surrounds suggest a western, "Victorian" influence (Fig. 35), rather than traditional Russian ornament in wooden architecture. Within its constricted dimensions the main facade is expressively designed with a variety of shapes, from a capacious low cupola over the main room on the left corner to a center gable to the culminating point on the right side: a steeply pitched turret above a large semicircular bay window that doubles as protection for the front door.

As of the beginning of the twenty-first century, many wooden houses remain in the historic districts of Chita, and some still preserve style moderne decorative elements 


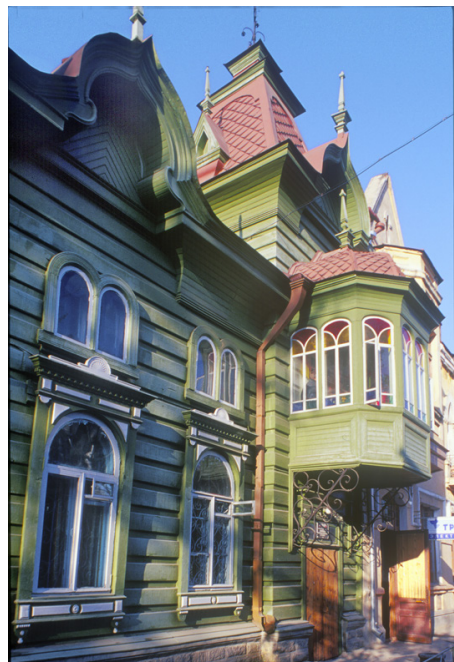

Fig. 35. Chita. M.D. Ignat'eva house, Anokhin Street 53. Photograph: William Brumfield (9/14/2000)

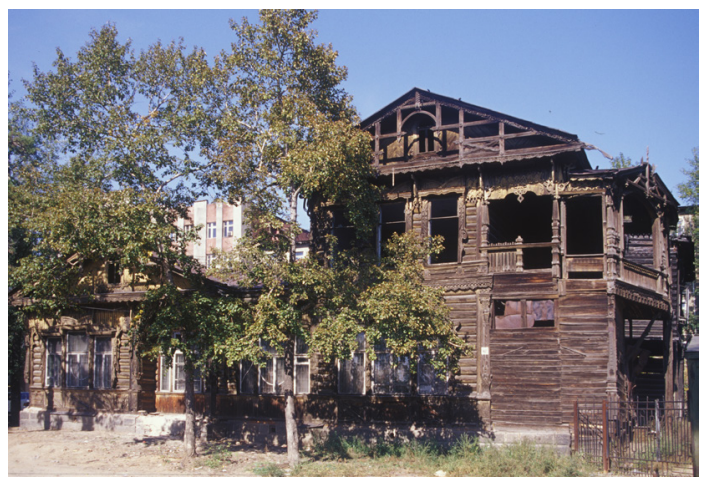

Fig. 36. Chita. S.A. Shilling house, Podgorbunskii Street 40. Photograph: William Brumfield (9/14/2000)

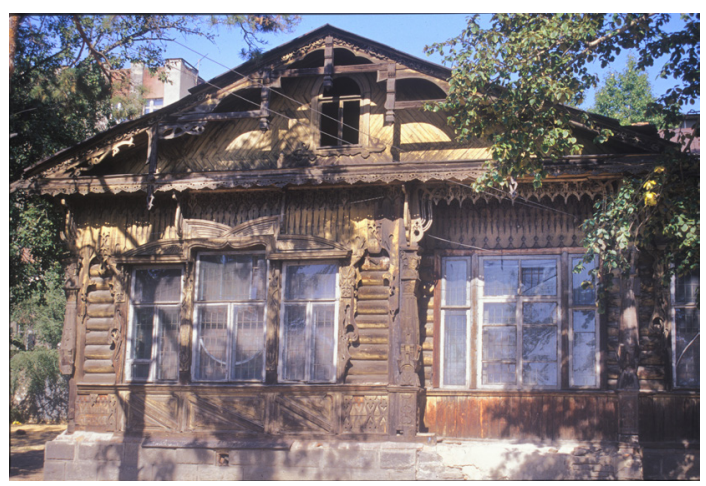

Fig. 37. Chita. S.A. Shilling house, Podgorbunskii Street 40. Side façade, window. Photograph: William Brumfield (9/14/2000)

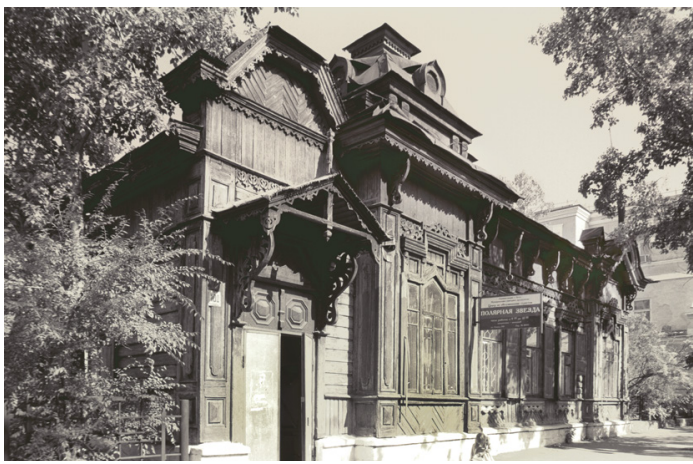

Fig. 38. Chita. Aleksandr V. Polutov house, Lenin Street 100. Photograph: William Brumfield (9/14/2000)

that seem so distinctively Siberian. ${ }^{76}$ One of the largest examples is the S. A. Shilling house, with its asymmetrical facade and florid window surrounds (Fig. 36, 37). One might call this style "frontier moderne." Yet as the current condition of the Shilling house demonstrates, few of these houses are properly maintained. Indeed, most of them are under threat as the city gradually rebuilds itself and land prices increase for centrally located sites. As elsewhere in Siberia and the Russian north, these houses were of $\log$ construction, usually clad with milled siding, such as the A.V. Polutov house (Fig. 38). In some cases, exemplified by the G.S. Kitaevich building, log dwellings were designed for multiple apartments or rooms to meet housing needs for the town's significant transient population (Fig. 39).

The most exuberant display of wooden ornamentalism in Chita is the M.M. Timokhovich house, built in 1910 (Fig. 40). The capacious onestory log house was designed by its owner, an agronomist whose fascination with going to sea expressed itself in the exuberant application of decorative piscine forms along the area beneath the cornice. ${ }^{77}$ Although the house is only a shadow of its former self, the wooden fish - large and small and even the bubbles from their mouths have been preserved despite the turbulence of Chita's history during the twentieth century. The vivid contrast 


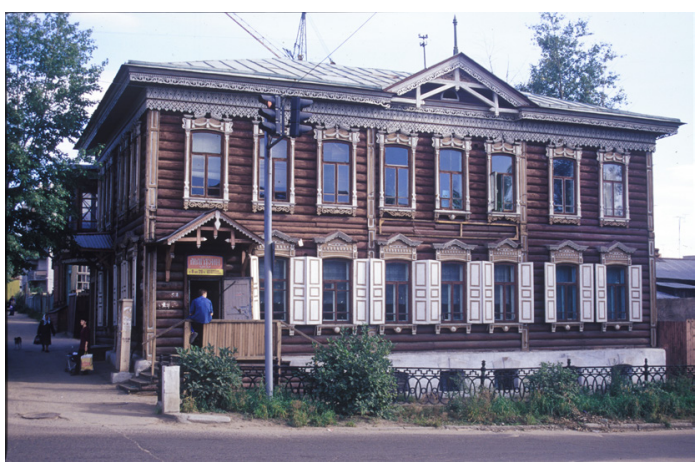

Fig. 39. Chita. G.S. Kitaevich house, Chkalov Street 83. Photograph: William Brumfield (9/14/2000)

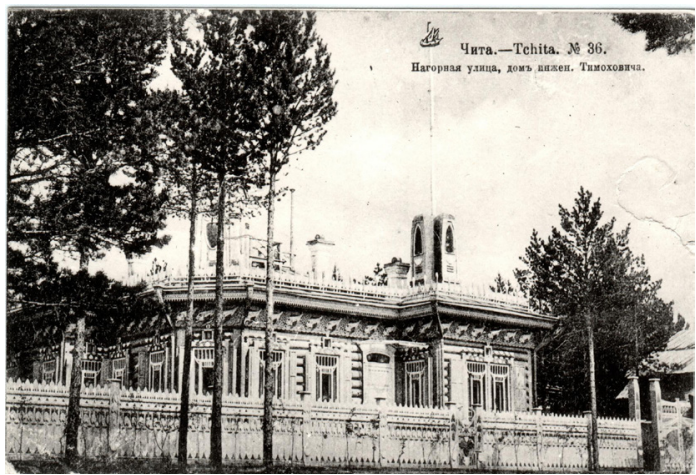

Fig. 40. Chita. M. Timokhovich house. Early 20thcentury postcard

between the stout $\log$ walls and the marine elements is further emphasized by art nouveau decorative touches, particularly in the lotus motifs of the painted window surrounds (Fig. 41).

Although primarily a town of wooden houses, Chita had sufficient wealth at the beginning of the century to support the construction of masonry houses, many of which display elements of a moderne style typical of fashionable residences in Russian provincial cities. ${ }^{78}$ The most distinctive representation of the modernist impulse is the A. D. Viazmin house, which combines elements of commercial architecture, an Italianate arcade (on the side façade) and a subtle use of decorative elements (Fig. 42). The culminative effect of the red brick structure shows a design sophistication that transcends the notion of "provincial"

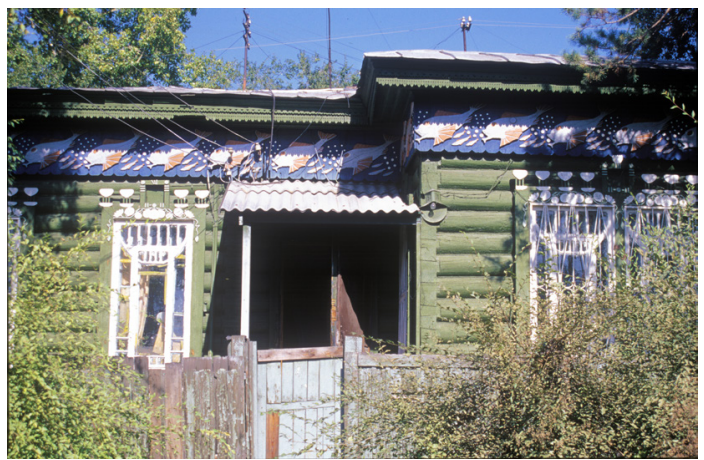

Fig. 41. Chita. M. Timokhovich house, Nagornaia Street 38. Photograph: William Brumfield (9/14/2000)

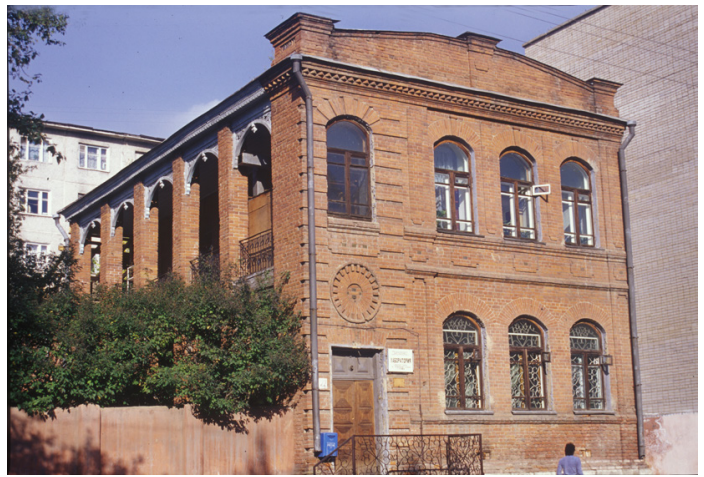

Fig. 42. Chita. A.D. Viazmin house, Chkalov Street 22. Photograph: William Brumfield (9/14/2000)

architecture. A similarly robust expression of early twentieth-century brick modernism is the main fire and police station, designed by Fedor Ponomarev with a boldly configured corner watch tower (Fig. 43).

A more traditional example of the new taste for mansions was the residence built in 1903 by the engineer Gavriil Nikitin, a graduate of the Imperial Academy of the Arts in Petersburg and Chita's leading architect at the beginning of the century. In its form and decorative detail, the Nikitin house (Fig. 44) derives primarily from the academic Beaux Arts style, freely interpreted. An idiosyncratic feature of the design is the fancifully ornamented belvedere that rises from the center of the roof. Vaguely pagoda-like with its accumulation of gables, the lookout would 


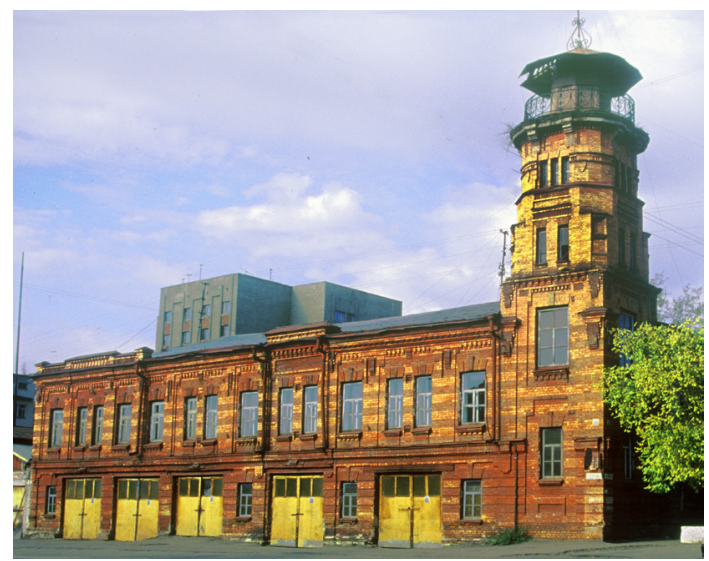

Fig. 43. Chita. Fire and Police Station, Chkalov Street 116. Photograph: William Brumfield (9/14/2000)

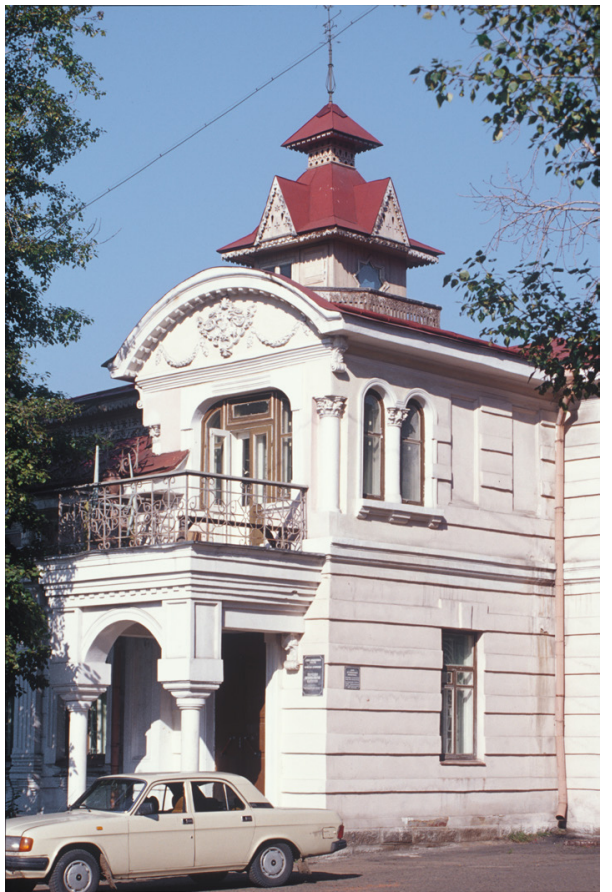

Fig. 44. Chita. Nikitin house. Photograph: William Brumfield (9/14/2000)

have provided at the time of its construction a sweeping panorama of dusty Chita.

Even before the establishment of Soviet power, the Nikitin house changed owners several times, and at one point even served as a workshop for making soap. Its most notorious resident was Grigorii Semenov, Cossack leader (ataman) and commander of anti-Bolshevik forces in the Transbaikal area. The proclamation of Soviet power in the area at the end of 1917 led to instances of severe repression, and when the forces of ataman Semenov seized Chita in August 1918, segments of the population endorsed his authority. No less important was the support of a Japanese military contingent, the result of Semenov's pro-Japanese politics.

Space does not allow a summary of the tangled events that marked Semenov's brutal misrule. ${ }^{79}$ The Bolshevik defeat and execution of Admiral Aleksandr Kolchak - Semenov's rival for power among White forces in Siberia - signaled the decline of the ataman's power, and during 1920 Semenov's forces were driven first from Chita and then from the entire Transbaikal area. New authority lay in the Far Eastern Republic, formed in Verkhneudinsk (now Ulan-Ude) in April 1920 and headquartered in Chita from November of

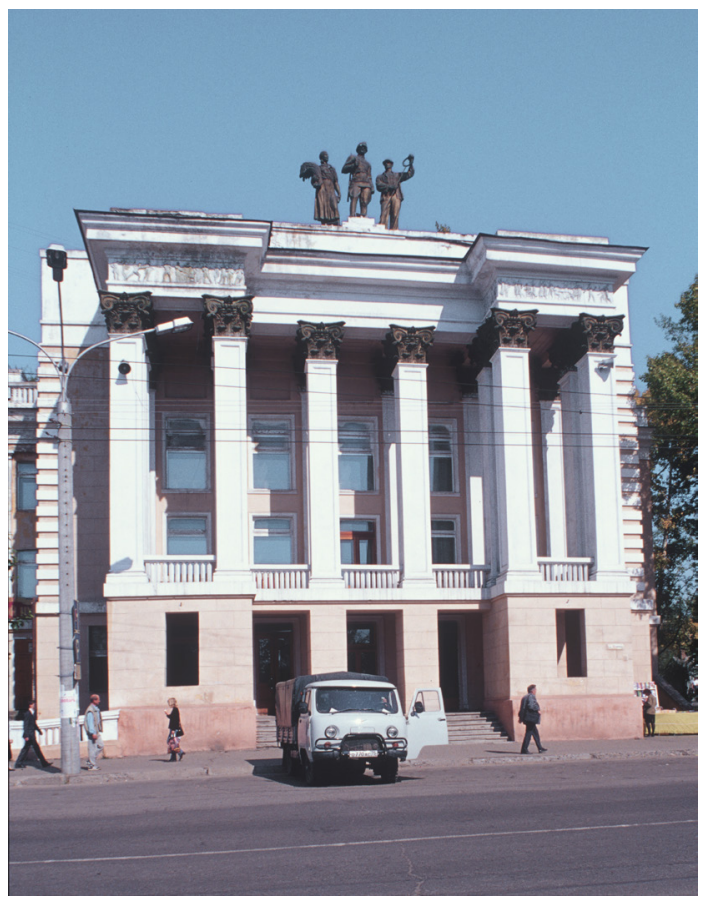

Fig. 45. Chita. Regional Building of Army Officers, Lenin Street. Photograph: William Brumfield $(9 / 14 / 2000)$ 


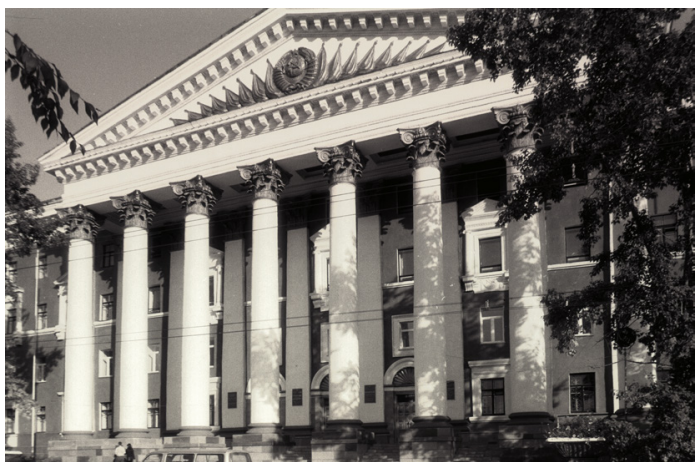

Fig. 46. Chita. Headquarters of TransBaikal Railroad. Photograph: William Brumfield (9/14/2000)

that year. Pro-Soviet in orientation, the republic served as a buffer to Japanese military operations in the Far East. Following the withdrawal of the Japanese, the Far Eastern Republic was merged into the newly formed Union of Soviet Socialist Republics in 1922.

During the Soviet era Chita reverted to its status as another provincial capital, albeit with critical strategic significance by virtue of its place in the national railway system and its proximity to the Manchurian border. Lacking a major industrial base, Chita's architecture experienced little impact of the functional, streamlined Constructivist designs of the 1920s and early 1930s.

With the late 1930s, however, construction began on a few carefully calculated showcase structures, such as the Regional Building of Russian Army Officers (1939-1940). Its massive entrance portico, in a modernized neoclassical style, signified the importance of the military presence in this border city (Fig. 45). Other applications of the Stalin-era neoclassical revival as a symbol of state power include the

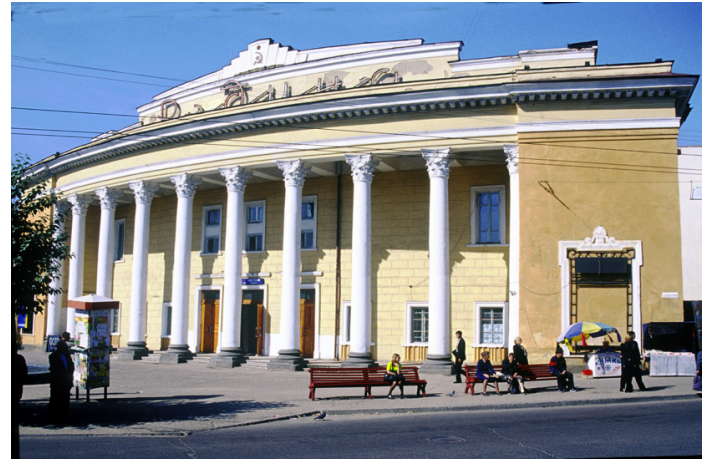

Fig. 47. "Rodina" Cinema, Chaikovskii Street 14. Photograph: William Brumfield (9/14/2000)

headquarters of the Trans-Baikal Railroad (an integral part of the Trans-Siberian), with its massive three-story Corinthian portico (Fig. 46). Chita's final expression of state-sponsored neoclassicism is perhaps the most successful: the Rodina ("motherland") Cinema, complete in 1956. Here the massive columns are integrated into a sweeping curved facade (Fig. 47).

The past half-century has contributed little of aesthetic note to the architecture of Chita. Both the late Soviet and post-Soviet eras have been characterized by solid but graceless multi-storied buildings. The city's treasures are its buildings from a century earlier, but their fate is uncertain. Some of the larger masonry structures have been well maintained, but the pervasive neglect of Chita's vibrant legacy of wooden architecture (primarily houses) has condemned many of these buildings to eventual destruction. In this respect, unfortunately, Chita joins almost every other provincial Russian city. It seems inevitable that many of these relics of Siberia's architectural heritage will soon exist only in photographs.

\footnotetext{
For a detailed survey of the early history of Nerchinsk, with historiographical commentary, see Aleksandr R. Artem'ev, Goroda $i$ ostrogi Zabaikal'ia $i$ Priamur'ia vo vtoroi poloviny XVII-XVIII vv. (Vladivostok: DVO RAN, 1999), 46-62. The name "Neliudskii" comes from the Russified form for the local Tungus tribe: "Neliudei" or "Neliulei".

On the Evenk Tungus, see V.A. Tugolukov, Tungusy (evenki i eveny) Srednei i Zapadnoi Sibiri (Moscow: Nauka, 1985). The burning of the Shilka fort is discussed in Artem'ev, Goroda i ostrogi, 47. In some cases extreme deprivation led Cossacks to attack Russian supply lines. See, for example, Aleksandr K. Borozdin, Protopop Avvakum (Saint Petersburg, 1898), 71-73; and Artem'ev, Goroda i ostrogi, 52.
} 
3 See A.R. Artem'ev, "Rossii vernoe sluzhenie (Rod kniazei Gantimurovykh)," in I.G. Striuchenko, S.B. Beloglazova, G.I. Subbot, eds., Zabytye imena (Vladivostok: Innokent'evskii komitet, 1994), 48.

4 A summary of the Pashkov expedition is provided in Pierre Pascal, "La conquête de l'Amour. Les campagnes de Pa\%okov," Revue des études slaves, 26(1950)1:15-16. Documents related to the expedition are contained in Dopolneniia k aktam istoricheskim, vol. 4 (Saint Petersburg, 1851), 40-41, 176, 178, 260-61. 272, 324.

5 Avvakum's description of the journey is presented in the authoritative edition of the vita of archpriest Avvakum edited by A.N. Robinson: Zhizneopisaniia Avvakuma i Epifaniia (Moscow: AN SSSR, 1963), 150-58. In English see Archpriest Avvakum: The Life written by Himself, translated and edited by Kenneth N., Bostrom (Ann Arbor: Michigan Slavic Publications, 1979), 61-76.

6 Despite the dangers from sudden and deadly Baikal storms, Pashkov's choice, made despite official instructions, was justified for a group so heavily burdened with provisions. Already in the mid-seventeenth century this became the accepted route into eastern Siberia (Dauriia). See Andrei A. Titov, Sibir'v XVII veke (Moscow, 1890), 30-31.

Robinson, Zhizneopisaniia Avvakuma, 249.

8 Events surrouding the creation of what would be known as the Nerchinsk fort are examined N.P. Kradin and M.Iu. Timofeev, "O date osnovaniia Nerchinskogo ostroga," Voprosy istorii, (1988)1:171-74.

9 Artem'ev, Goroda i ostrogi, 49.

10 Commentary on the relations between Avvakum and Pashkov is contained in Robinson, Zhizneopisaniia Avvakuma, 242$43,246,255$.

11 Avvakum himself noted the punishments inflicted on those under Pashkov's command, both at Yeniseisk and during the journey. See Robinson, Zhizneopisaniia Avvakuma, 249.

12 On the reduction in numbers, see Galina A. Leont'eva, "K voprosu ob obrazovanii postoiannogo sluzhilogo naseleniia v Vostochnoi Sibiri vo vtoroi polovine XVII-nachale XVIII vv. (Nerchinskii uezd)," in Voprosy istorii sotsial'no-ekonomicheskoi i kul'turnoi zhizni Sibiri i Dal'nego Vostoka, 2(1968): 42.

13 Artem'ev, Goroda i ostrogi, 49. See also Leont'eva, "K voprosu," 44.

14 Artem'ev, Goroda i ostrogi, 49.

15 The defection of other leaders is noted in Georgii V. Melikhov, Manch'zhury na Severo-Vostoke (XVII v.) (Moscow: Nauka, 1974), 67.

16 For more information on the extraordinarily bold and skillful demarches of Arshinskii, see Vladimir S. Miasnikov, Imperiia Tsin i Russkoe gosudarstvo v XVII veke (Moscow: Nauka, 1980), 125-27; published in English as The Ch'ing Empire and the Russian State in the Seventeenth Century, translated by Vic Schneierson (Moscow: Progress Publishers, 1985). See also Artem'ev, Goroda i ostrogi, 50-51.

17 See Galina A. Leont'eva, Zemleprokhodets Erofei Pavlovich Khabarov (Moscow: Prosveshchenie, 1991), 144.

18 Artem'ev, Goroda i ostrogi, 104.

19 N.P. Kradin, "Krepost' Albazin. Oboronnoe stroitel'stvo na Severo-Vostoke russkogo gosudarstva v XVII veke." in Rossiia i ATR, 1(1992):67-79. See also Artem'ev, Goroda i ostrogi, 105, 277, 280

20 On the agricultural development, see A.R. Artemev, Iu.A. Sem, A.I. Sergeev. "Khoziaistvennoe osvoenie Dal'nego Vostoka russkim naseleniem," in A.I. Krushanov, ed., Istoriia Dal'nego Vostoka SSSR v epokhu feodalizma i kapitalizma: XVII v.-fevral' 1917 g. (Moscow: Nauka, 1991), 48-51.

21 Artem'ev, Goroda i ostrogi, 106-07.

22 Viktor I. Shunkov, Ocherki po istorii zemledeliia Sibiri (XVII v.) (Moscow: AN SSSR, 1956), 221.

23 Artem'ev, Goroda i ostrogi, 108-09.

24 Miasnikov, Imperiia Tsin, 250. For commentary in English on the Treaty of Nerchinsk, see Mark Mancall, Russia and China; their diplomatic relations to 1728 (Cambridge: Harvard University Press, 1971).

25 Among works on Russia's trade with China, see Clifford Foust, Muscovite and Mandarin; Russia's trade with China and its setting, 1727-1805, (Chapel Hill: University of North Carolina Press, 1969).

26 The first log church of the Nerchinsk-Dormition Monastery burned in 1729. On the Church of the Dormition, with plans, see N.P. Kradin, "Pamiatniki arkhitektury Nerchinska XVIII-XIX vv.", in Arkhitekturnoe nasledstvo, 33(1985):78-88.

27 See for example, the Church of the Ascension (1698-1704) at the Ascension Monastery in Solikamsk (Ural Mountains) in William C. Brumfield, "Photographic Documentation of Architectural Monuments in the Northern Districts of Perm Province," Visual Resources, 18(2002):30-31.

28 See Kradin, "Pamiatniki arkhitektury Nerchinska," 81.

29 On the relocation of Nerchinsk, see Artem'ev, Goroda i ostrogi, 60.

30 A more detailed discussion of the Resurrection Cathedral is contained in Kradin, "Pamiatniki arkhitektury Nerchinska," 82.

31 See Nikolai D. Muzgin, Gorod Nerchinsk: K 325-letiiu osnovaniia goroda (Irkutsk: Vostochno-Sibirskoe knizhnoe izdatel'stvo, 1978).

32 On the Nerchinsk Gostinyi Dvor, with plan, see Kradin, "Pamiatniki arkhitektury Nerchinska," 82-83.

33 A first-hand account of the Nerchinsk silver mines is provided in George Kennan, Siberia and the Exile System, 2 vols. (New York: The Century Co., 1891), 2:278-318. Kennan correctly notes that the silver mines are spread over a large territory extending northward from Mongolia and not at all near to the town itself.

34 Recent research on the Decembrists in the Irkutsk and Trans-Baikal areas is presented in Zemlia Irkutskaia, 5 (1996).

35 Mikhail Dmitrievich Butin, Sibir'i ee doreformennye sudy (Saint Peterburg: Narodnaia pol'za, 1898), 36.

36 Nikolai Ruposov, “Soli-zlodeiki suseki stoiat...”, Zemlia irkutskaia, 2(1994):19.

37 Evidence provided by Leonid Boleslavich Kandinskii. See also www.kandinsky.ru.

38 The village of Biankino is now classified as "uninhabited" on the official map Chitinskaia oblast, Aginskii buriatskii avtonomnyi okrug (Moscow: Roskartografiia, 1994). 
39 Remarkably little information has been published on Kandinskii's ancestral background. One brief but relatively detailed excursus is contained in D.V. Sarabianov and N.B. Avtonomova, Vasilii Kandinskii: put' khudozhnika, khudozhnik i vremia (Moscow: Galart, 1994), 103.

40 Ruposov, "Soli-zlodeiki," 19.

${ }^{41}$ Natal'ia Gavrilova, "Sibirskii Amerikanets," Zemlia irkutskaia, 12(2000): 24; Ruposov, "Soli-zlodeiki," 19-20.

42 Ruposov, "Soli-zlodeiki," 20. The impact of the Butins' far-flung retail trade is also noted in Kennan, Siberia, 2:324.

43 These rivercraft and barges were produced at the Butins' Nikolaevskii iron foundry. See Gavrilova, "Sibirskii Amerikanets," 25; Ruposov, "Soli-zlodeiki," 22.

44 On Mikhail Butin's trip to China, see Gavrilova, "Sibirskii Amerikanets," 24-25.

45 Mikhail Dmitrievich Butin, Istoricheskii ocherk snoshenii russkikh s Kitaem (Irkutsk, 1871), 6.

46 On the Russian Empire's subsequent economic and political moves into Manchuria, see David Wolff, "Russia Finds its Limits. Crossing Borders into Manchuria," in Stephen Kotkin and David Wolff., eds., Rediscovering Russia in Asia: Siberia and the Russian Far East (Armonk, N.Y.: M.E. Sharpe, 1995), p. 40-54.

47 On the Butins' stake in the Darasun gold mines and the application of American mining technology, see Gavrilova, "Sibirskii Amerikanets," 24-25; Ruposov, "Soli-zlodeiki," 20. The Butins' innovations are further discussed in Sergei F. Khrolenok, Zolotopromyshlennost' Sibiri: 1832-1917: istoriko-ekonomicheskii ocherk (Irkutsk: Izdatelstvo Irkutskogo Universiteta, 1990), 76-77.

48 Mikhail Dmitrievich Butin, Pis'ma iz Ameriki (Saint Peterburg, 1872). Excerpts containing Butin's ruminations on America's growth at Russia's expense are presented in Gavrilova, "Sibirskii Amerikanets," 27-28.

49 Butin, Pis'ma iz Ameriki, 54.

50 Mikhail Butin's philanthropic work is noted in Kradin, "Pamiatniki arkhitektury Nerchinska," 82; and Gavrilova, "Sibirskii Amerikanets," 26. Butin himself mentions these activities in Sibir'i ee doreformennye sudy, 4, 20.

51 Kennan, usually the quintessential gentleman, is quite uncharitable toward poor Klementovich, to the point of saying that his exile would be justified by the execrable state of the hotel. See Kennan, Siberia, 2:321.

52 Ibid., 2:323-24. The interior furnishings are also noted in Kradin, "Pamiatniki arkhitektury Nerchinska," 83-85.

53 Kennan, Siberia, 2:324.

54 These reverses included the Irkutsk fire of 1879, that destroyed warehouses and goods; a severe drought in the early 1880 s that reduced the all-important water supply at their gold works; and the loss of ships with merchandise from Odessa and Hamburg. On the financial problems of the Butin firm, see Gavrilova, "Sibirskii Amerikanets," 26; and Ruposov, "Soli-zlodeiki," 22.

55 Kennan, Siberia, 2:17.

56 Ruposov, "Soli-zlodeiki," 26.

57 A general plan of the Butins' Nerchinsk compound is presented in Kradin, "Pamiatniki arkhitektury Nerchinska," 85.

58 Chekhov's Ostrov Sakhalin was serialized in the journal Russkaia Mysl' in 1893 and 1894. The first complete publication appeared in 1895. See A.P. Chekhov: Polnoe sobranie sochinenii i pisem, 30 vols., Sochineniia (Moscow: Nauka, 1974-), 14-15:773. A recent English edition is entitled: A Journey to Sakhalin, translated by Brian Reeve (Cambridge, England: I. Faulkner, 1993).

59 Chekhov's Siberian travel notes, Iz Sibiri, appeared serially in Aleksei Suvorin's newspaper Novoe Vremia during the summer of 1890. See Chekhov: Polnoe sobranie, sochineniia, 14-15:762.

60 Chekhov wrote the letter on board the "Ermak," steaming down the Shilka River. Chekhov: Polnoe sobranie, Pis'ma, 4:118.

${ }_{61}$ For more detail on the decoration of wooden houses in Nerchinsk, see Kradin, "Pamiatniki arkhitektury Nerchinska," 87-88.

62 Nikolai E. Dvornichenko, Putevoditel' po Chite: dostoprimechatel'nosti, pamiatniki i pamiatnye mesta (Irkutsk: Vostochno-Sibirskoe knizhnoe izdatel'stvo, 1981), 2-9.

63 The reconstruction of the Church of the Archangel Michael is discussed in L.G. Poletaeva, "Nashi dukhovnye tsennosti," in M.V. Konstantinov, Innokent'evskie chteniia. Nauchno-prakticheskaia konferentiiia posvishchennaia 200-letiiu Innokentiia Veniaminova (Chita: ZGPU, 1998), 83.

${ }_{64}$ For examples of northern Russian log church architecture, see William Brumfield, Russkii sever. Svidetel'stvo Uil'iama Brumfilda (Moscow: Gosudarstvennyi muzei arkhitektury im. Shchuseva and Izdatel'stvo Tri Kvadrata, 2001).

${ }^{65}$ On the decision to retain the church as the Decembrist Museum in the post-Soviet period, see Poletaeva, "Nashi dukhovnye tsennosti, 84-85.

${ }_{66}$ Kennan's book recounts two visits to Chita, the second of which lasted almost two weeks. The account also contains sketches by George Frost of log houses associated with the Decembrists in Chita. Kennan, Siberia, 2:128-30; 329-42.

67 Ibid., 329. On the Buriats, Kennan noted: "The natives in Siberia known as Buriat's are nearly all Lamaists."

68 See Wolff, "Russia Finds its Limits," 44.

${ }^{69}$ I am indebted to the Center for the Preservation of the Historical Cultural Heritage of Chita oblast', and its director, Tatiana Zherebtsova, for providing me with a number of these early twentieth century views. Specialists at the center also shared archival information for a number of the building annotations that follow in this chapter.

${ }^{70}$ Russia, with Teheran, Port Arthur, and Peking; handbook for travellers by Karl Baedeker (Leipzig: K. Baedeker; New York: Charles Scribner's Sons, 1914), 534.

71 Most of the leaders of the "Chita Republic" of 1905 were executed. One who survived was V.K. Kurnatovskii, a lifelong revolutionary who was personally acquainted with Vladimir Lenin and Nadezhda Krupskaia. Although captured by Meller-Zakomelskii and sentenced to death by Rennenkampf, Kurnatovskii escaped and ultimately made his way to Paris, where he died in poverty in 1912.

72 An analysis of the design of apartment buildings in Saint Petersburg during the latter half of the nineteenth century is contained in Andrei L. Punin, Arkhitektura Peterburga serediny XIX veka (Leningrad: Lenizdat, 1990), 250-77; and William Craft Brumfield, The Origins of Modernism in Russian Architecture (Berkeley: University of California Press, 1991), 1-47. 
73 Information on these and other early twentieth-century buildings in Chita is drawn from the archives of Center for the Preservation of the Historical Cultural Heritage of Chita oblast'.

74 On the Vtorov firm's commercial architecture in Moscow, see Brumfield, The Origins of Modernism, 285-87.

75 The Catholic church was originally built as a chapel in 1851 and expanded in 1898. The Catholic parish ceased to exist in 1926, and the property was given to the city's Orthodox community, which occupied the building only in 1944. One Orthodox structure that survived the Soviet period is the Missionary School (1889), but the other buildings in this complex known as the Archbishop's Legation and located at the edge of Cathedral Square -were destroyed. It should be noted that the number of Orthodox churches in Chita before the revolution was relatively small. The physical destruction of Russian Orthodoxy during the Soviet period in Chita can be partially explained by the close support given by local church hierarchs to the counterrevolutionary regime of Ataman Semenov during the Russian civil war. See V.I. Vasilevskii, "Iz istorii Zabaikal'skoi eparkhii v gody beloi gosudarstvennosti," in M.V. Konstantinov, Innokent'evskie chteniia, 80-82.

76 A detailed analysis of style and design in the wooden houses of Chita at the beginning of the twentieth century is provided in P.V. Baklyskii, "Elementy moderna v dereviannoi arkhitekture goroda Chita," in N.P. Kradin, ed., Arkhitektura vostochnoi Sibiri i Dal'nego Vostoka, vyp. 1, Russkie goroda na Dal'nem Vostoke (Khabarovsk: KhGTU, 2002), 40-54.

77 Subsequent losses in the ornamentation of the Timokhovich house are noted Ibid., 52-53.

78 In the scale of modern construction Chita was eclipsed by its rival on the Chinese Eastern Railway, Kharbin, founded as a Russian settlement in 1898. Kharbin's strategic location on the Russian-sponsored railroad network in Manchuria led to an explosive growth in building activity at the beginning of the twentieth century. Although situated in Manchuria and thus beyond the purview of this study, its early twentieth-century architecture - much of which survives to this day - is a dramatic example of the influence of major Russian architectural styles in these distant outposts of empire. See S.S. Levoshko, "Istoriko-arkhitekturnoe issledovanie Kharbina," in N.P. Kradin, ed., Arkhitektura vostochnoi Sibiri i Dal'nego Vostoka, vyp. 1, 167-92; and N.P. Kradin, Kharbin - russkaia Atlantida (Khabarovsk: Khovrov A.Iu., 2001).

79 A detailed account of the Siberian conflict is contained in Jonathan D. Smele, Civil War in Siberia: The Anti-Bolshevik Government of Admiral Kolchak, 1918-1920 (New York: Cambridge University Press, 1996). See also Jamie Bisher, White terror: Cossack Warlords of the Trans-Siberian (New York: Frank Cass, 2005): and James William Morely, The Japanese Thrust into Siberia. 1918 (New York: Columbia University Press, 1954).

\section{Историческое архитектурное наследие}

Читинской области в Восточной Сибири

\section{У.К. Брумфильд Университет Тулейн США, Луизиана, Новый Орлеан}

В статье рассматривается архитектурное наследие территории Читинской области (также известной как Забайкальский край) в рамках исторического контекста начиная с середины XVII века и заканчивая Советским периодом. После исследования событий, которые привели к российской экспансии и закреплению территорий, рассматривается история архитектуры двух городских центров: Нерчинска и Читы. Оба города тесно связаны с торговлей с Китаем. В статье упоминается работа Михаила Бутина, предпринимателя и автора, являющегося основателем большой производственной базы в Нерчинске. Особое внимание уделено примечаниям Джорджа Кеннана о Нерчинске в его двухтомной работе «Сибирь и система ссылки». Также рассматриваются впечатления Антона Чехова. В последней части статьи прослежсивается расивет Читы, связанньй с бурным развитием Транссибирской магистрали в начале XX века. Также отмечены события, связанные с революииями 1905 и 1917 гг. и Гражданской войной в России.

Ключевые слова: архитектура Сибири, Чита, Нерчинск, Албазин, Иркутск, озеро Байкал, p. Ингода, p. Шилка, иарь Алексей Михайлович, Петр Бекетов, Афанасий Пашков, Аввакум, сибирские казаки, буряты, Ерофей Хабаров, династия Манчу Цин, Михаил Бутин, Джордж Кеннан, Сибирь и система ссылки, Василий Кандинский, Транссибирская магистраль, дизайн в стиле модерн, современная архитектура стиля, Александр Второв, Читинская синагога, Атаман Григорий Семенов.

Научная специальность: 24.00.00 - культурология. 